\title{
Seventy Years of Pottery Studies in the Archaeology of Mesolithic and Neolithic Sudan
}

\author{
Giulia D'Ercole (D)
}

Accepted: 15 March 2021 / Published online: 17 April 2021

(C) The Author(s) 2021

\begin{abstract}
This review article examines seventy years of research and methodological approaches to the analysis of Mesolithic and Neolithic pottery in Sudan. It begins with the studies done by A. J. Arkell at the end of the 1940s, leading to the definition of the Khartoum Mesolithic and Khartoum Neolithic ceramic traditions. The article then discusses the application of the concepts of ware, fabric, decorative technique, and chaine opératoire to the analysis of pottery and the use of new classification tools and archaeometric methodologies. The implication of the concepts of cultural encounter and the communicative role of material culture for ceramic studies and the insights that ceramics can provide for understanding the interrelationships between humans and the landscape are also discussed.
\end{abstract}

Résumé Cet article examine soixante-dix ans de recherche et approches méthodologiques de l'analyse de la poterie mésolithique et néolithique au Soudan. L'article commence par les études menées par A. J. Arkell à la fin des années 1940, aboutissant à la définition des traditions céramiques de Karthoum pendant les périodes concernées. Outre l'utilisation de nouveaux outils de classification et de méthodologies archéométriques, l'article aborde l'application des concepts de typologie, de pâte, de technique décorative et de chaîne opératoire à l'analyse de la céramique. Les

G. D'Ercole $(\bowtie)$

Ludwig Maximilians-Universität München, Schleißheimer Strasse 4, 80333 Munich, Germany

e-mail: Giulia.Dercole@aegyp.fak12.uni-muenchen.de

e-mail: giuliadercole9@gmail.com implications des concepts de rencontre culturelle et le rôle communicatif de la culture matérielle pour les études sur la céramique, ainsi que les connaissances que cette dernière peut offrir pour comprendre les interrelations entre l'homme et le paysage, sont aussi traités.

Keywords Pottery · Sudan · Mesolithic · Neolithic · Archaeometric analyses

\section{Introduction}

Ceramics have always played a prominent role in archaeological material culture studies. Ceramic production represents the earliest chemical and physical transformation process deliberately operated by humans dating to $12 \mathrm{kya}$ in the Sahel and southern part of the Sahara (Huysecom et al. 2009) and has since been ubiquitous in archaeological sites. Arguably, no class of artifacts has been as versatile as pottery in understanding human behavior. On the one hand, a pot is an object of daily use, relatively simple in form and very tangible. On the other hand, even an ordinary vessel concentrates human creativity, technological awareness, and social complexity.

Ceramic objects have been studied and interpreted from several perspectives, for their aesthetic value, as tools having technological and functional meanings (e.g., Braun 1983; Müller et al. 2010; Schiffer and Skibo 2008), and for their social and cultural significance (e.g., Gosselain 1998; Roux 2013; Stark et al. 2000). Theoretical approaches to the study of pottery are as diverse as geography, local research traditions, 
and archaeological premises and questions. For example, for several years, pottery studies in central, eastern, and southern Africa used ceramics as proxies for recognizing ethnic groups and linguistic identities - e.g., the spread of the Bantu language speakers. This approach has been criticized, and alternative directions have been offered (see, among others, Ashley 2010; Lane 2015). In Near Eastern archaeology, the standardization and innovations in ceramic forming techniques, such as the potter's wheel, have been used to understand the paths toward social complexity and urban expansion (see Baldi and Roux 2016; Roux 2008). Some other theoretical, conceptual, and methodological developments can be recognized worldwide. For example, pottery has been studied as a craft object focusing on the analysis of manufacturing processes. There are also studies emphasizing ceramic functions through use-wear and residue analyses for reconstructing foodway traditions and practices. Moreover, there are ceramic studies that privilege cultural encounters, networks, and dynamics of cultural hybridization (e.g., Dunne et al. 2012; Gosselain 2008; Lindahl and Pikirayi 2010; Livingstone-Smith 2016).

There has also been an increasing application of hard science methods to archaeological material in general and ceramics in particular.

How do these scientific methodologies meet and combine with traditional humanistic and historical approaches in archaeology? How does the latest abundance and diversity of scientific methods affect the notion of material culture and the interpretation of human behavior? Taking advantage of the experiences I had in the field of archaeometry as a link between archaeologists and the hard scientists, I offer a review of seventy years of research on Mesolithic and Neolithic pottery in Sudan and provide a broader comparison with other African regions.

\section{Ceramics and Ceramic Studies in the African Continent}

In Africa, the art of making pottery is a ten thousand-year tradition. The earliest ceramic containers made their appearance between the tenth and the mid-ninth millennium $\mathrm{BC}$ and were produced by early Holocene huntergatherer societies living between western Africa (i.e., Mali) (e.g., Huysecom et al. 2009), the Sahara desert (e.g., Casanova et al. 2020; Garcea 2001; Roset 1996), the Egyptian Western Desert (e.g., Close 1995; Schild and Wendorf 2010; Schön 1996), and the middle Nile Valley (e.g., Garcea et al. 2016; Honegger and Williams 2015; Khabir 1987a). In eastern Africa (i.e., Kenya, Tanzania), the first use of ceramics is recorded c. $6000 \mathrm{cal} \mathrm{BC}$ in association with a delayed return of hunter-gatherer economy (e.g., Ashley and Grillo 2015). In southern Africa, for the most part, ceramics appeared in the archaeological record during the period $290 \mathrm{cal} \mathrm{BC}$ to cal $\mathrm{AD} 310$ with the arrival of farming communities (Kinahan 2013; Lander and Russell 2020). In the southeastern part of South Africa (Karoo region), pottery possibly appeared before the so-called Iron Age Bantu migrations (Sadr and Sampson 2006). In this area, it is likely that a specific type of pottery (i.e., fiber-tempered pottery) represents a local innovation among hunter-gatherers (Lander and Russell 2020, p. 23).

Ceramic studies in Africa have a tradition of just over a hundred years, recently celebrated by Gosselain and Livingstone Smith (2013) in a publication that highlights archaeological and ethnographic approaches. In the beginning, the Africanist ceramic studies followed a primarily descriptive approach that aimed to build typological lists and seriations based on pottery's aesthetic and morphological traits (e.g., Caton-Thompson, 1931). This approach, inherited from a culture-historical tradition and brought to Africa by Egyptologists (e.g., Peet 1933; Petrie 1921), dominated the research framework for at least fifty years.

The 1960s were characterized by the trend away from subjective and unsystematic classifications toward a more robustly systematic analysis of pottery's diverse attributes (i.e., style, size, morphology). Many studies on ceramic assemblages from various African regions date back to these years (e.g., Bailloud 1969; CampsFabrer 1966; Posnansky 1961). Despite the claim of objectivity, these studies still maintained a strong focus on the external appearance of the vessels and the idea of type "as the expression of general time/space relationships which allow the formulation of chronologies and the tracing of patterns of cultural change" (Wright 1968, p. 67). Meanwhile, outside of Africa, the concept of ceramic technology started to be developed thanks to Anna Shepard (1956). She was the first to stress the importance of studying the technological traits of pottery, besides stylistic and morphological characteristics, through the analysis of fabrics.

The first significant turning point for pottery studies in Africa occurred in the late 1960s and 1970s with the 
advent of processual archaeology. The so-called attribute analysis approach (after Dunnel 1971, 1986), which became established during the 1970s in both eastern and southern Africa, is a product of processualism (Ashley and Grillo 2015). Processual archaeology also charted the course for using ceramics to study technology, performance, use-wear, and functional variability. During the same period, another school of technological ceramic studies was established in the subfield of ethnoarchaeology. This focuses attention on the manufacturing processes in ethnographic contexts (e.g., Crossland and Posnansky 1978 at Begho, Ghana; Gallay 1970 in Mali; Haaland 1978 in Darfur, Sudan). Ethnoarchaeological approaches to the chaîne opératoire of ceramic production caught on, especially in western Africa. In this region, but not exclusively, numerous field studies developed in archaeological (e.g., Gallin 2002; Garcea 2005; Mayor 2010) and ethnographic contexts (e.g., Gosselain 2008; Livingstone Smith 2000).

Recently, there have been new publications on African ceramics by interdisciplinary teams who offer a 360degree perspective that combines traditional stylistic and technological analyses with archaeometry, including optical microscopy (OM), scanning electron microscopy (SEM), X-ray diffraction (XRD), X-ray fluorescence (XRF), instrumental neutron activation analysis (INAA), and organic residue analysis. Although archaeometric studies of ceramics are increasingly popular in African archaeology (e.g., Dunne et al. 2018; Eramo et al. 2020; Fewlass et al. 2020), these methodologies are not yet widespread, and some regions lag behind others (Ashley and Grillo 2015, p. 466).

\section{Mesolithic and Neolithic Periods in Sudan: Cultural and Ecological Premises}

In Sudan, the earliest ceramics date from the mid-ninth millennium BC and come from Site 2-R-66-Amara West, northern Upper Nubia (Garcea et al. 2016); Busharia I-Kerma, Upper Nubia (Honegger and Williams 2015); and Sorourab II-central Sudan (Khabir, 1987a; Mohammed-Ali 1982) (Fig. 1). The early pottery in the region was produced by sedentary or semi-sedentary hunter-gatherers or pre-pastoral groups, who settled in the mosaic ecological environments of the early Holocene (c. 10,000-6300 BC) that developed at the onset of the humid period (see Kuper and Kröpelin 2006; Macklin et al. 2015; Zerboni 2013). During this time, in the northernmost parts of the Sudanese Nile Valley (e.g., Sai Island, in northern Upper Nubia), precipitations occurred during the winter months and hunter-gatherers settled in an open savannah type of vegetation with seasonal fresh water (Florenzano et al. 2016). In Upper Nubia (Kerma region), the landscape was dominated by extensive alluvial plains, terraces, and paleochannels (Honegger and Williams 2015; Macklin et al. 2015). In central Sudan, the region of Khartoum was characterized by a more humid wooded savannah vegetation due to intense summer rainfall (Williams 2019; see also Hildebrand et al. 2018; Fig. 1).

The part of the Nile Valley between Old Dongola and Debba was directly connected through the west with the Erg Ennedi and Gebel Tageru massifs by a network of channels and tributaries, including the Wadi Howar and the Wadi El Melik (Kröpelin 2007). Human occupation in these western regions started later than along the Nile Valley. In the Lower Wadi Howar, sites were located in the plains and on fossil dunes which were stabilized by vegetation around 7000 BC but occupied only during the sixth and fifth millennium BC (Jesse 2003a, 2006a; Keding 2000); and in the Middle Wadi Howar, long-term sites are documented from c. 5300 BC (Hoelzmann et al. 2001; Fig. 1). In eastern Sudan, early occupations by hunters and gatherers are recorded from the second half of the sixth millennium BC, particularly in the northern Gash delta (north of Kassala, near the border with modern Eritrea) (Fattovich 1989; Manzo 2017) and in the area of Kashm el-Girba (south of Kassala, on the western bank of the upper Atbara River) (Marks 1987; Sadr 1991). Additionally, other sites related to those from Kashm-el Girba were documented by Manzo et al. (2012) east of the Atbara river (Fig. 1).

People living in the middle Nile Valley during the early Holocene were strongly dependent on exploiting wild animals, local seeds, and plants. Most lived on riverine and lacustrine resources (Linseele and Zerboni 2018; see also Iacumin et al. 2016). However, there were also sites located in the hinterland, such as Shaqadud in Butana, on the steppe of eastern Sudan (Fig. 1). The inception of ceramic technology in these communities was associated with the increased sedentism and the need to process and store local wild cereals, fish, and aquatic food (e.g., Garcea 2016; Haaland 2007; Maritan et al. 2018). 


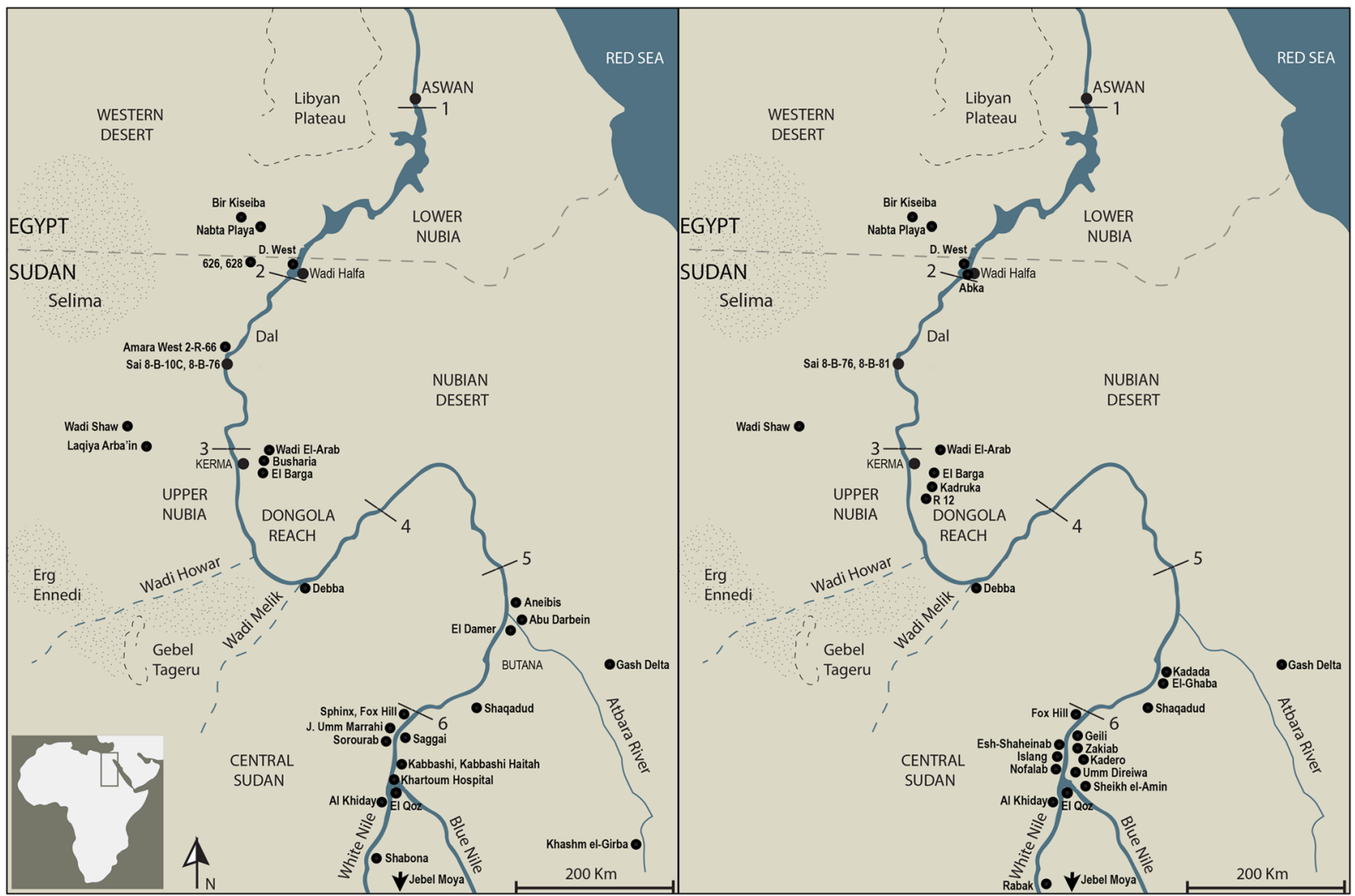

Fig. 1 Nubia and central Sudan with the main Mesolithic (left) and Neolithic (right) sites cited in the text (adapted from D’Ercole, 2017)

Hunter-gatherers buried their dead. Pre-pastoral (Mesolithic) burials and cemeteries are known from Upper Nubia (Honegger 2004), central Sudan (e.g., Jebel Sabaloka west, Sixth Cataract; Varadzinova and Varadzin 2017), and the White Nile Valley (e.g., AlKhiday; Salvatori et al. 2011) (Fig. 1). However, grave goods were rare, and pottery was almost never used as a funerary good. The discovery of a large Wavy Line pot fragment in Khartoum Hospital site, in burial M21, apparently used as a pillow for the deceased, is an exception (Arkell 1949, p. 31). In general, the custom of using ceramics as funerary equipment only began during the Neolithic period.

The early Holocene ceramic traditions are associated with different local cultural complexes: Early Khartoum or Wavy Line Culture in central Sudan, Khartoum Variant in northern Sudan, and Pre-Saroba phase and Amm Adam group in eastern Sudan. Starting from the mid-Holocene, pottery was produced under novel economic and cultural conditions: either by huntergatherers who adopted a pastoral economy (this model of adaption was defined as a "pastro-foraging" economy and used by Kuper and Riemer (2013) for describing the economic scenario of the Egyptian Western Desert) or by pastoralist groups who initially had a few domestic animals. At Sai Island, the Abkan pastoral groups (5500-3700 cal BC) settled at the same site as the previous Khartoum Variant foragers (e.g., Site 8-B-76), while other groups coexisted with foragers for a certain time (e.g., Site 8-B-81) (Garcea et al. 2016). The earliest evidence of domesticated livestock in Sudan comes from the El Barga cemetery, Kerma, Upper Nubia (5750 cal BC). From c. 5300 BC, the region of Kerma was re-occupied by pastoralist communities who established their settlements near the Nile on the newly emerged alluvial plain (Honegger and Williams 2015). In central Sudan, the climate relatively humid for some time, with precipitation levels and Nile floods similar to the early Holocene pattern. This climate regime allowed the survival of a riverine savannah environment still suitable for fishing and hunting and also favorable for cattle grazing (Dunne et al. 2018). The Khartoum Neolithic (also known as Shaheinab Neolithic from the site-type of Esh Shaheinab) started at the beginning of the fifth millennium BC. It was characterized by the 
coexistence of large permanent sites (e.g., Esh Shaheinab, Geili, el Kadada, and Kadero) and small sites used seasonally for specific economic activities (e.g., Zakiab, Umm Direiwa; Caneva 1988; Haaland 1987; Krzyzaniak 1991).

In western Sudan, most of the tributary wadis of the Nile (e.g., Wadi Howar and Wadi Melik) remained active until c. 4000 BC (Nicoll 2004; Woodward et al. 2001). However, there was never a cohabitation of hunter-gatherers and herders. Nevertheless, from the end of the fifth millennium $\mathrm{BC}$, the latter replaced the former (Jesse et al. 2013; Keding 2000). In eastern Sudan, the exploitation of the wet environment established along the Atbara river and near watercourses in the hinterland possibly lasted until the mid-fifth millennium BC (e.g., Malawiya Group). Pastoralist cultures developed later, contemporaneous with the Late Neolithic in central Sudan (e.g., Butana Group; Manzo 2017).

The transition to fully specialized pastoralism, characterized by high mobility, took place in the fifth millennium BC. This transition particularly occurred in specific areas of Sudan (e.g., Butana region, Wadi Howar), and often together with the establishment of Nile-desert transhumance routes. The different pathways to pastoralism, and the interrelations that developed between hunter-gatherers and pastoralists, depended on the timing and ways in which the new economic strategies (pastoralism and, in some regions, also farming) combined or replaced previous ones. The specific climatic and environmental conditions in the various sectors of the Valley and the hinterlands, following the $6300 \mathrm{BC}$ climatic change, also affected the modalities of these economic transitions (see Garcea 2020, chapter 5; Salvatori and Usai 2019; Wengrow et al. 2014).

\section{Arkell's Early Khartoum Mesolithic and Khartoum Neolithic}

The association of late prehistory in Sudan with a Mesolithic ceramic horizon and a later Neolithic horizon is due to Arkell's discoveries at the sites of Khartoum Hospital, Esh Shaheinab, and El Qoz at the end of the 1940s through the early 1950s (Arkell 1949, 1953). In his 1949 publication, Arkell defined two main cultural phases, named the "Wavy Line Culture" or "Early Khartoum" (later re-named "Khartoum Mesolithic") and the "Gouge Culture" (or "Khartoum Neolithic"). These were followed by the "Omdurman Bridge Culture," a contemporary of the Egyptian protodynastic period. Despite some obvious limitations of his reports due to the context in which they were produced and some inaccuracies in the description of the assemblages (discussed below), Arkell has the undeniable merit of being the first to recognize and illustrate some key aspects of the Late Prehistory of central Sudan. The most significant of these is the presence of a Mesolithic (Early Khartoum) phase, with no evidence of food production but which yielded pottery, prompting Arkell (1949, p. 111) to describe this as "an interesting contrast to the Natufian in Palestine, which had sickles but not pottery."

With reference to the classification of the ceramic assemblages, Arkell identified the wavy line as the decorative motif typifying the earliest Mesolithic phase. However, the description of this decoration is given in a subjective and partially puzzling way: "it was decorated with a comb moved horizontally and at the same time up and down, so as to produce a number of parallel wavy lines" (Arkell 1949, p. 81). The author provides an accurate picture of the tool used for making the wavy line pattern (a comb made out of a catfish spine i.e., Synodontis schal), but he is more vague concerning the technique, which one can assume to be an incision only by contrast to what he further wrote about the dotted wavy line and other impressed patterns (Fig. 2).

The dotted wavy line motif is described as a "variety of the ordinary Wavy Line decoration" produced "by combing a band of wavy lines in the ordinary way, and then impressing dots by the rocker technique along the wavy lines so formed" (Arkell 1949, p. 84). At first, Arkell did not explicitly mention the relationship between the two in chronological terms. Rather, he wrote that "the Dotted Wavy Line was not entirely coincident with ordinary Wavy Line in either time or space..." (Arkell 1949, p. 85). Later, referring to the stratigraphic deposit of the site of El Qoz, which he excavated to understand the Mesolithic-Neolithic sequence, Arkell (1953, p. 101) reported that "the maximum of the Gouge Culture sherds occurs above the maximum of the Wavy Line sherds, with the maximum of Dotted Wavy Line sherds between them." Thus, he recognized the Dotted Wavy Line as a "typological link between the pottery of the Khartoum Mesolithic and the pottery of the Khartoum Neolithic" (Arkell 1953, p. 69; see 
Fig. 2 Catfish spine (from recent Synodontis schal) combs used for making the wavy line pattern and examples of incised wavy line sherds from the Site of Khartoum Hospital (modified from Arkell, 1949, pls. 59 and 61)
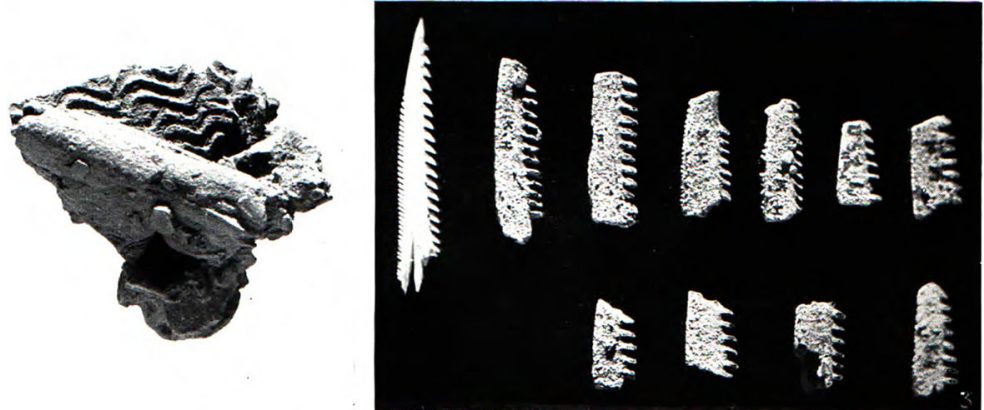

WAVY LINE POTTERI FICS. I \& IA SCAIE 4:0
FIGS 2, 3 SCALE 1:I

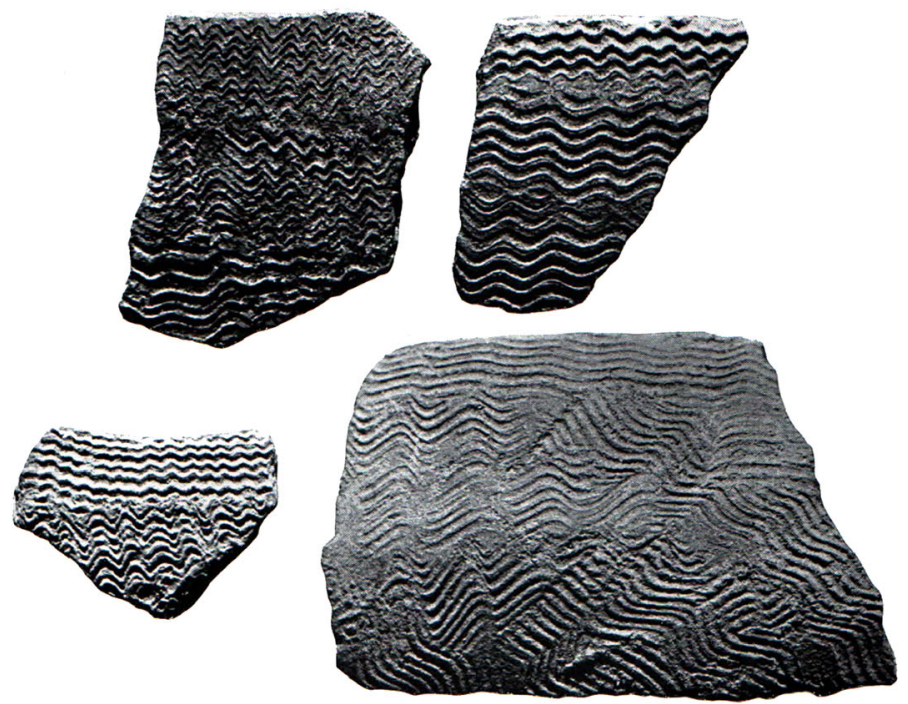

also Caneva 1983; Garcea 2006a). Some of the stylistic differences between the Mesolithic and Neolithic dotted wavy line variants, and the difference between the form and the length of the waves, were only vaguely addressed by Arkell (cf., Hays 1971; Jesse 2002; Mohammed-Ali and Khabir 2003). However, he made a preliminary distinction based on surface treatment, recognizing that the Shaheinab Neolithic production was burnished, while the early Khartoum dotted wavy line was not (Arkell 1953, 1972). Likely, he was the first to internalize the concept of "ware" as the set of the stylistic and technological traits of the pottery.

Nevertheless, according to the trends of the time, Arkell, and other scholars working in the Sahara after him, attributed a preeminent value to the stylistic aspects of pottery based on the belief that the spread of certain innovations (so-called guide fossils or cultural markers) might have coincided with the physical movement of people. This produced now discredited diffusion theories between east and west (from the Nile Valley to the Sahara) and vice versa, together with the definition of broad culturaltechnical complexes, such as the "Neolithic of Sudanese Tradition" (Hugot 1963), the "Saharan-Sudanese Complex" (Camps-Fabrer 1966), and the "Khartoum Horizon Style" (Hays 1971). Since then, the designation of horizon style relating to the distribution of the wavy line and dotted wavy line motifs, and to the possible contacts and cultural affinities between the various cultures of the Nile Valley and adjacent areas, has been discussed and revised many times (e.g., Mohammed-Ali and Jaeger 1989). In 2003, following a thorough spatial and temporal analysis of the two ceramic types, Mohammed-Ali and Khabir (2003, p. 49) concluded: 
...it is evident that both wavy line and dotted wavy line ceramics were associated with sites whose economies were based on seasonal hunting, fishing, and wild grain-collecting, and the same subsistence economy was later supplemented by stock-herding and possibly incipient cultivation. Nonetheless, their spatial-temporal distribution is not invariably synchronous.

While the wavy line pottery seems to represent a "pottery mode tradition," the dotted wavy line calls for a "horizon style" phenomenon.

In this statement, the authors were using the concept of "pottery tradition" as defined by Willey (1945, p. 53) in which pottery development can be delineated "through time within the confines of a certain technique or decorative constant." The transmission of these styles during certain periods and over a large geographical area delineates a "horizon style."

\section{Nordström's Early Nubian Cultures and Definition of Fabric}

In the $1960 \mathrm{~s}-1970 \mathrm{~s}$, research on the late prehistory of Nubia and Sudan intensified, following the construction of the Aswan High Dam and the International Rescue Campaigns to Save the Monuments of Nubia (for an overview, see Adams 2007). Myers (1958, 1960) first excavated a group of sites south of the border between Egypt and Sudan. A few years later, Shiner (1968a, p. 768) attributed these sites to the Khartoum Variant culture. Other sites around the Second Cataract, confined to the immediate banks of the Nile, were called Abkan, following the ideal-type site of Abka (Fig. 1; Shiner, 1968b). At first, it was believed that Abkan and Khartoum Variant horizons were partially contemporary although they displayed different features and were therefore considered "distinct entities" (Shiner, 1968a, p. 789). In 1972, Nordström suggested a revision of the entire chronological sequence for the Abkan culture, which was "redated" as younger than the Khartoum Variant. According to him, the Khartoum Variant seems to be related to the earlier part of the so-called Khartoum techno-complex, while the Abkan group belongs to the later phase (Nordström 1972, p. 17). According to the current chronology of northern Upper Nubia, the Khartoum Variant period dates between c. 8000 and $4900 \mathrm{cal} \mathrm{BC}$, and the Abkan period is dated to between c. 5500 and 3700 cal BC (Garcea 2020, chapters 4 and 5).

Methodologically, Nordström provided a substantial contribution to the advancement of knowledge of the early Nubian ceramic assemblages. In his work, he referred to the view of Anna Shepard (1956), that "the primary aim of a ceramic analysis is to reconstruct the general conditions for the potters and to place in a cultural context the various factors that guided their work" (Nordström 1972, p. 34). Therefore, he organized his classification of ceramics in a systematic way, arranging the analytical data in a taxonomic system made up of five different property groups: (1) fabric; (2) surface properties; (3) vessel shape; (4) decoration; and (5) size. The term fabric encompasses the set of compositional and anthropogenic characteristics of the ceramic material that could be determined by microscopic observation and comprised of the groundmass and non-plastic inclusions and the potter's choices (technology) in the making of the vessel.

Nordström attributed the Khartoum Variant pottery to the general Ware Family K, defined as "Sand-Tempered Ferruginous Fabrics," which was divided into two fabric groups. The first is characterized by a fine sandy paste (Fabric IA), the second by a micaceous texture (Fabric IB). This pottery was described as having "uncompacted grainy surfaces decorated on the exterior with impressed designs" (Nordström 1972, p. 48-49, 58). This ware family showed affinities with the Early Khartoum ceramics from the sites of central Sudan described by Arkell. The pottery of the Abkan tradition (Ware Family $\mathrm{M}$ ) was assigned to a single fabric group (Fabric IC). It is "a medium- or low-grade fabric with a sandy paste" containing mineral inclusions and some carbon particles. Nordström (1972, p. 49, 58-60) described this fabric as having some similarities with the Khartoum Neolithic pottery from Esh Shaheinab. The Abkan wares were either undecorated or decorated by impression or incision and often showed burnished surfaces. In general, besides the description of the fabric types, Nordström's classification scheme was based on combinations of different visual and morphometric attributes of the vessels, but it mainly applies to intact vessels such as those found at Nubian A-Group sites. Therefore, there are clear limitations in the application of his model to analyzing prehistoric assemblages where pottery is primarily found in fragmentary conditions (Gatto 2002, p. 65-66). 


\section{Caneva's Ceramic Classification System, the Chaîne Opératoire Approach, and Other Classificatory Systems}

Isabella Caneva developed a different methodological approach to the macroscopic study of ceramics in the 1980s. She applied similar methods focused on reconstructing the chaines opératoires of the technological productions of both lithic and ceramic assemblages from Saggai (Caneva and Zarattini 1983). In addition to the Early Khartoum site of Saggai, she applied the same classificatory system to the assemblages from the Neolithic site of Geili, also in central Sudan (Caneva 1983, 1988; Caneva and Marks 1990; Fig. 1). Considering that the majority of these ceramics were decorated, Caneva's classification laid the basis for the assumption that "the aesthetic significance of the motifs, as well as the technical relevance of a single, perhaps occasional, tool, are beyond our possibility of evaluation" (Caneva 1989, p. 376). Consequently, her classification criteria focused on the technical features of the various components involved in the production of ceramic decorations rather than their visual aspect. She introduced new hierarchic, interrelated categories that correspond, de facto, to the successive steps adopted by the potter to produce the decorative patterns. Starting with the technique and the implement used, she distinguished the element, the motif, and ultimately the structure of the decoration (Caneva 1983, 1988; Caneva and Marks 1990). In order to reconstruct this sequence, Caneva performed laboratory replications and compared them with archaeological assemblages.

Regarding Early Khartoum pottery, Caneva distinguished between two main decorative techniques: impression with a rocker, both comb and two-toothed tool, and incision with a comb. The rocker impression, made with denticulated combs, produces bands of dotted zigzags which can be further classified as packed zigzags, spaced zigzags, or zigzags with spaced dots and dashes. Also, the rocker decorations can be made with plain edge combs producing straight or curved zigzags. The dotted wavy lines are bands of dotted zigzags with dotted wavy line effect. This pattern was obtained by using rocker stamp impression, "first pivoting the comb on one end until the edge has made a fan of impressions, and then by reversing the movement" (Caneva 1989, p. 377). Conversely, the wavy line was obtained by incision with a similar comb. In the stratigraphic deposit of Saggai, Caneva observed that the "rocker technique is always highly used, but its rate of application, including the dotted wavy line, increases very markedly toward the upper levels. The wavy line decreases accordingly" (1983, p. 188).

The rocker impression produced during the Neolithic period was made on burnished sherds and obtained with a tool having either a plain or a serrated edge. As the length of the edge of the instrument and the number and shape of the comb's teeth determine the different decorative motifs, the main innovation was that the Neolithic dotted wavy line motif resulted from a different technique using a two-toothed implement. This technique was used similarly to the rocker, which was called "alternately pivoting stamp." It was first identified in the assemblage from Geili and the Acacus (Libya) (Caneva 1987), and later at Shaqadud (Caneva and Marks 1990; cf. Mohammed Ali 1991).

Caneva's classification system offered several innovative contributions. First, following the foundations laid out by the work of Henriette Camps-Fabrer in the 1960 s, it shifted attention from the purely aesthetic value of the decoration to its technological feature, specifically from the mere classification of the decorative style to the understanding of the intention and the gestures produced by the ancient potter to decorate the vessel. Second, Caneva's classification has the advantage of being adjustable in conformity to the state of preservation of the material. In this respect, it is possible to classify even very small potsherds, where it is possible only to identify the element (e.g., dots and dashes) of the implement used to make the decoration (cf. Nordström 1972).

Currently, Caneva's system is the most broadly employed classificatory method for the prehistoric pottery of Sudan, Sahara, and the Sahel (e.g., Haour et al. 2010). Many scholars working with African ceramics have used, integrated, or adapted this classification system (e.g., Gatto 2002). Hence, based on Caneva's system, Jesse (1998) proposed the terms "Incised Wavy Line" (IWL) and "Dotted Wavy Line" (DWL) to describe the wavy patterns resulting from the impression technique, while "Wavy Line" remained in use as a comprehensive definition, including both types of decorations (Jesse 1998, 2002, p. 80). Furthermore, Jesse (2002, 2003b, 2004) paid more attention to the observation of the individual aspects of decorative motifs. The result was an in-depth analysis of the distribution of dotted wavy line and wavy line patterns across various regions in Northeast Africa, based on length (long 
vs. short waves) and structure (covering vs. zonal motifs) of the decoration.

Other macroscopic classificatory systems have been used for the study of Sudanese prehistoric ceramic complexes. One of these is the "type-variety" (typological) classificatory method developed in late 1950. The method was first applied by Hays (1971), and Marks et al. (1985), and later to the ceramic assemblage from Shaqadud by Winchell (2013). Fundamental to the type-variety classification is the definition of a type by a pattern of modes. A type "is a specific kind of pottery embodying a unique combination of recognizably distinct attributes, and that this pottery, as well as being the product of a certain cultural configuration, has a definable areal distribution and temporal significance" (Gifford 1960, p. 341). A sherd or a vessel can share a set of similar reoccurring attributes among many other variant attributes (see also Smith et al. 2014). For his classification of the Butana Group pottery, Winchell based his type-variety method on both the visual and physical parameters of pottery (e.g., pastes, inclusions, and surface treatments). He integrated Caneva's categories to describe the surface treatments and decorations although he did not follow her hierarchy.

Garcea (2005) also provided a classificatory system that marked an important step forward for the analysis of Saharan and Sudanese pottery (see also Garcea and Caputo 2004). The system is based on studies focusing on ceramics, cultural identities, and technological behaviors (e.g., Gosselain 2000; Livingstone Smith 2000). It also uses a relational database in which data are organized in a nested hierarchy through a grid of linked user forms (Garcea 2006a, p. 101). Garcea's approach integrates information collected on the decorative aspects of pottery assemblages following Caneva's classification, all and including the other steps of the manufacturing process: from raw material procurement, assessment, and preparation of the clay, to production and finishing, until the phases of use and discard of the pots. Thus, although the classification of the pastes and textures relies on an autoptic assessment of the material, this database represents a useful interface between macroscopic and microscopic analysis. Garcea's database has been used for the study of the ceramics from Esh Shaheinab (Garcea 2006a, 2006b) and Sai Island (D'Ercole 2017; Garcea 2012; Garcea and Hildebrand 2009), as well as for the analysis of the assemblages from numerous Saharan and Sahelian contexts (Garcea $2005,2008,2013)$. Lately, this classification system has been applied to the study of ceramic assemblages of the Early Khartoum site of Sphinx, at Jebel Sabaloka, in combination with petrographic and chemical analyses (Garcea et al. 2020; see below). Meanwhile, Michael Brass has reassessed the ceramic complexes of Jebel Moya (southern Gezira) and Shaqadud (western Butana) (Brass and Schwenniger 2013; Brass 2016; Brass et al. 2018). He proposes an "attribute analysis" system that emphasizes the tools and the motor actions used for making decorations rather than the techniques and the decoration motifs (Brass et al. 2018: 43; cf. Caneva and Marks 1990). This system focuses on the specificity of archaeological contexts and chronology, and permits "the selection of the appropriate attributes pertinent to the questions being asked" (Brass et al. 2018, p. 23).

Overall, there is a multitude of different approaches and macroscopic classificatory systems that have been used for grouping and classifying Sudanese prehistoric ceramics. Some of them (e.g., the type-variety system) are taxonomic classifications as they consist of typological categories and variables ordered hierarchically according to ranked classes. Such systems have the advantage of being intuitive, apparently objective, and virtually adaptable to any context of study. However, their alleged universal character ("single-best-typology") risks providing monolithic typologies that hardly adapt to specific contexts (Dunell 1971; Smith 1979). On the other hand, paradigmatic classification systems based on unbiased categories (e.g., rank) (Dunnel 1971, p. 84 , see also Ness 2015 , p. 311-312) are possibly more flexible (e.g., Brass's attribute analysis). Nevertheless, the analyst must be aware of the danger of excessive details and redundant information. Also, as these typologies are often customized for single specific contexts, they may become problematic if applied to a variety of contexts.

Caneva's classification consists of a "priority sequencing of attributes grouped in a dendritic arrangement with [a] different diagnostic value representing different decisions for the potter" (Caneva and Marks 1990). Although this classification is based on a taxonomic logic and the various categories of her sequence are all co-dependent, some categories may be given a higher value than others, resulting in a possible emphasis on the motif and element of the decoration. This inconvenience partly depends on the experience of the ceramic analyst, the level of knowledge of the context, and overall familiarity with the method of classification. 
Also, quantitative data should be combined with detailed qualitative descriptions of the ceramic assemblage, including an interpretative reading of the overall decorative modes, stylistic choices, and technological features of the vessels. In these terms, Caneva's system and Garcea's query database should be considered analytical tools for developing a critical interpretation of the ceramic corpus.

\section{Ceramic Classifications and Cultural Spheres or Traditions Along the Nile Valley and Adjacent Regions}

A detailed classification of the ceramic data can lead to a better definition of the geography of human cultures. This has been the case along the Nile Valley and adjacent regions where discrete cultural spheres or traditions have been defined, based on ceramic data (e.g., Caneva et al. 1993; Garcea and Hildebrand 2009; Brass 2016). Stylistically, the Early Khartoum ceramics of central Sudan (c. 8500-5000 cal BC) are characterized by different varieties of incised wavy lines and impressed wavy line decorations (including, among others, rounded and angular wavy lines, and the so-called archshaped motifs) (Caneva 1991 p. 266-267, 1996, p. 232-233; Jesse 2004, p. 297). Impressed motifs also comprise rocker-stamped zigzags made of dots and dashes, and combinations of waves and rows of zigzag impressions. In the Khartoum area, the long wave type of dotted wavy lines (on an average 20 to $40 \mathrm{~mm}$ long) is predominant, while short waves (7 to $8 \mathrm{~mm}$ long) are known from a few sites only (i.e., Kabbashi, El Qoz) dating from the late sixth millennium BC (Caneva 1996, p. 233; Jesse 2002, p. 92). In central Sudan, the Early Khartoum decorations, either incisions or impressions, are arranged in a continuous structure and cover the entire surface of the vessel. However, the Khartoum Variant (c. 8000-4900 cal BC) assemblages in Lower Nubia and northern Upper Nubia lack incised wavy lines but are characterized by the presence of dotted wavy line motifs produced with small-sized combs (with 3-4 teeth) and arranged in a banded structure (D'Ercole 2017; Garcea and Hildebrand 2009). The dotted wavy lines of the short wave type also comes from El Barga, near Kerma, dating from the Mesolithic III Phase (c. 7200-6300 BC) (Honegger 2014). Outside the Nile Valley, this pattern appears on early Holocene ceramics in the Egyptian Western Desert (Gatto 2002).
The Early Khartoum ceramic types are widespread. They are recorded in virtually all early Holocene hunter-gatherer sites of central Sudan, including the Khartoum province, the region of Sabaloka (Sixth Cataract), both on the eastern (Nassr 2016) and western Nile banks (Varadzinová and Varadzin 2017), as well as further to the north in the Atbara region (Haaland 1987; Haaland and Magid 1995; Fig. 3).

Moving northwards, incised wavy line decorations have been discovered in the so-called Karmakol cultural complex (formerly named Early Khartoum Related) of the Dongola Reach and Fourth Cataract (6500-6100 cal BC) (Garcea 2020; Marks et al. 1968). In this area, however, ceramics are tempered with the vegetal matter, while Early Khartoum pottery from Khartoum is generally mineral-tempered (Gatto 2006a), although there are examples of vegetal-tempered pottery at Khartoum Hospital site (see Arkell 1949). South of Khartoum, mineraland vegetal-tempered Early Khartoum ceramics have been found across the White Nile (Clark 1989; Salvatori 2012; Salvatori et al. 2011, 2014; Usai 2016) and Blue Nile Valley (Fernandez et al. 2003).

In western and eastern Sudan, the early ceramic complexes associated with a hunting-gathering economy have been described with different terminologies, such as: Dotted Wavy Line/Laqiya pottery in the Wadi Howar in western Sudan; and Pre-Saroba and Saroba pottery at Khashm el-Girba, in eastern Sudan. These only partially display affinities with the Early Khartoum tradition (Fattovich et al. 1984; Jesse 2002, 2004; Keding 2000; Marks and Fattovich 1989). Furthermore, early Holocene pottery from Jebel Moya and Shaqadud exhibits only some traits typical of Early Khartoum decorations. For example, at Shaqadud, spaced zigzags and, in general, spaced elements (e.g., spaced dots/dashes) are particularly abundant compared to the Nile Valley (Caneva and Marks 1990, p. 20). At Jebel Moya, Addison (1949) originally published photos of dotted wavy line pottery, and Caneva (1991) first linked this material to the Late Mesolithic period (late sixth millennium BC). Recently, Brass et al. (2018) validated the existence of dotted wavy line pottery at Jebel Moya, including long and short types. These date from the late Mesolithic, although with no indication of incised wavy lines.

Besides wavy line incised and impressed motifs, other decorations typical of early Holocene assemblages include rocker-stamped zigzags, alternately pivoting stamped parallel lines, and simple impressions. There 
Fig. 3 Early Khartoum ceramics from the western part of Jebel Sabaloka, with dotted wavy line and wavy line motifs (courtesy of Czech Institute of Egyptology, Faculty of Arts, Charles University, 2011)

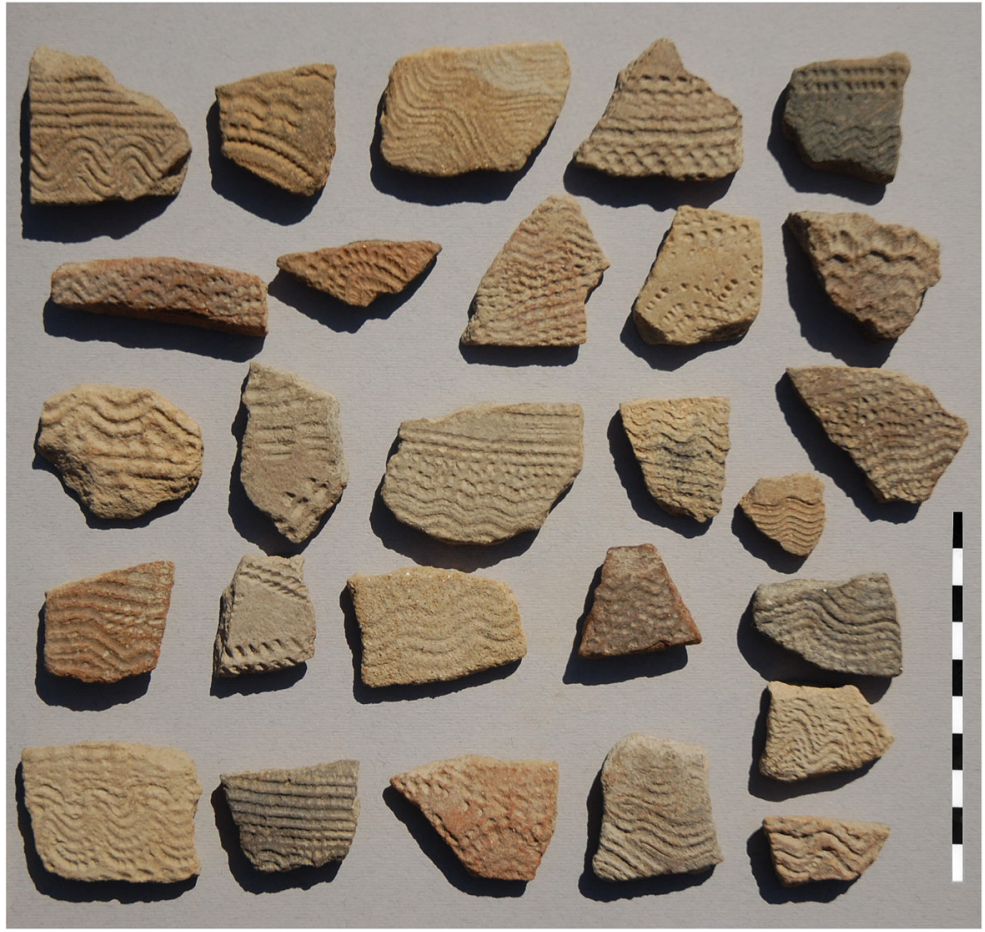

are also rare occurrences of decorations resulting from the roulette technique (Garcea et al. 2020, p. 121, fig. 22) and the rocker technique using a roulette tool instead of a comb (D'Ercole 2017, p. 84, plate 3.13). It is worth noting that in some regions, some of these decorative motifs (e.g., alternately pivoting stamped lines in the region of Kerma and Sai Island) appear at an earlier time than wavy line patterns (see D'Ercole 2017, p. 59; Honegger 2014, p. 23, plate 1). In terms of morphology, most early Holocene hunter-gatherer ceramics seem to be homogeneous, including shapes such as bowls and globular jars, most likely manufactured using the coiling technique (Caneva 1983; Garcea 2020).

The Esh Shaheinab Neolithic ceramics (c. 50003800 cal BC) in central Sudan mostly exhibit inner and outer burnished surfaces and vessel walls, generally thinner than Early Khartoum pottery. Surfaces show a greater variety of decorative motifs, mainly obtained by rocker impression or alternately pivoting stamping. Interestingly, the use of unevenly serrated-edged tools became common, resulting in complex decorative motifs (e.g., zigzags with "vees and dots") that cover the entire vessel surface. Fine wares include blackburnished and red-burnished vessels, either undecorated or decorated only around the rim (Garcea 2020, p. 121124, figs. 6.3-6.6). Compared to the Early Khartoum tradition, there is a greater variety of vessel shapes and types. Domestic wares can be clearly distinguished from the funerary vessels, such as caliciform beakers, and various types of bowls, jars, and dishes known from the Neolithic cemeteries of Kadruka (Maines et al. 2018; Reinold 2001, 2006), Kadero (Chlodnicki et al. 2011), and Ghaba (Salvatori et al. 2016).

In Upper Nubia (Kerma region), Early Neolithic (c. 6000-5500 BC) ceramics are burnished and decorated with rocker stamps (Honegger 2014; Honegger and Williams 2015). Later ceramics (c. 5000-4000 BC) include fine pastes with burnished or polished surfaces, undecorated or decorated with single impressions near the rim, along with black-topped and ripple wares, which resemble certain vessel types seen at Abkan and later A-Group sites in Lower Nubia (D'Ercole 2017, p. 160). Similar wares were recognized in the northern Dongola Reach (e.g., at Kadruka, and at the cemetery R12, south of Kerma and Kadruka). In this area, the pottery of the Middle Neolithic A phase (first half of the first millennium BC) shows similarities with the Neolithic production in central Sudan. The pottery is characterized by a wide range of shapes, mainly ovoid/ spherical, with completely decorated surfaces, polished surfaces, and ripple ware) (Salvatori 2008, p. 11, fig. 13.1b; see also David and Salvatori 2019; Usai 2016). In 
Lower Nubia, Abkan pottery (c. 5500-3700 BC) represents a very distinctive local tradition, likely more disconnected from the Khartoum Variant than Shaheinab Neolithic pottery from the Early Khartoum phase (D'Ercole 2017; Garcea et al. 2016; Nordström 1972). So far, no funerary sites containing pottery have been found for the Abkan period in Lower and Upper Nubia.

The pastoralist communities settled in the Middle Wadi Howar at the beginning of the 4th millennium $\mathrm{BC}$ and produced characteristic ceramic types (Leiterband-style ceramics), which correlate in part to the Shaheinab Neolithic tradition (Keding 1998, 2000). Conversely, in the Lower Wadi Howar, herringbone patterns indicate possible contacts with the Nubian Nile Valley (Jesse 2006b, p. 68; Jesse and Keding 2007, p. 42). Interestingly, in eastern Sudan, the Neolithic pottery of the Butana Group (4th-early 3rd millennium BC) shows some stylistic aspects (i.e., burnished ware, rippled ware, black-topped ware, and herringbone motifs) also found on Pre-Kerma ceramics from Upper Nubia (c. 3600-2500 BC), which can be taken as indirect evidence for long-distance networks involving the circulation of specific luxury items (Manzo 2017, p. 22, $31)$.

\section{Ceramic Fabrics and Archaeometric Laboratory Analyses}

The interest in ceramic production and technology in Sudanese prehistory started fifty years ago. Pioneering petrographic and compositional works had been carried out on Mesolithic and Neolithic ceramic assemblages by several scholars, including Chlodnicki (1984, 1989), De Paepe (1986, 1991), Francaviglia and Palmieri (1983, 1988), Hays and Hassan (1974), Khabir (1987b, 1991a, 1991b, 2014), and Nordström (1972, 1981) (Table 1). The use of archaeometric approaches in ceramic analysis has gained ground over the past decade in Sudanese archaeology. This trend shows the application of advanced scientific tools and increased sampling budgets for long-term interdisciplinary projects (see Klein et al. 2004, in the framework of the ACACIA project in the Wadi Howar). Some of the latest projects in which archaeometric methods have been used include the excavations conducted at the sites of Al-Khiday, White Nile Valley (Dal Sasso et al. 2014; Usai et al. 2018), and Kabashi Haitah, near Saggai (Antonelli et al. 2018). A large project combining excavation, survey, and material culture studies is ongoing at Sabaloka east, led by Al-Neelain University in Khartoum (Nassr 2016). Additionally, a comprehensive study joining macroscopic observations of the stylistic and manufacturing techniques and petrographic $(\mathrm{OM})$ and compositional analyses (iNAA), as well as analyses of absorbed organic residues (GC-MS and GC-C-IRMS), is currently in progress on the western bank of Sabaloka (for the site of Sphinx, see Garcea et al. 2020). Concerning northern Upper Nubia, a key contribution comes from the diachronic analysis of the ceramic complexes on Sai Island (Table 1). These latest studies integrated stylistic and morphological classification of ceramics with petrographic and mineralogical analysis of pastes. The various analytical techniques are applied in a complementary way to answer a wide range of research questions, including the recipe of pastes (what?), the technology of production (how?), and the provenance of vessels (where?). These works share a focus on the intersection of typological data with chronological/stratigraphic, and archaeometric results, as well as broader evaluation of geological and environmental contexts (Fig. 4).

Overall, the Early Khartoum, Early Khartoum-related, and Khartoum Variant hunter-gatherer ceramics are generally similar in technological terms, despite regional stylistic differences. Depending on the proportion in which the various mineral and rock components were present, these Mesolithic pastes have been basically distinguished between quartz-rich- and alkali feldsparrich fabrics (the latter being perhaps the majority), whereas the grain size of inclusions and specific mineralogical and petrographic features allowed recognition of further sub-groups or fabrics (e.g., Antonelli et al. 2018; Dal Sasso et al. 2014). During the Neolithic period, ceramics of the Sudanese Nile Valley were mostly made of alluvial clays containing fine sandsized quartz grains together with plagioclase feldspar, accessory minerals, and rock fragments. In addition to mineral inclusions, Neolithic and Abkan vessels were commonly tempered with organic matter (e.g., charcoal particles, herbivore dung, and vegetable fibers [see D'Ercole 2017]).

One possible explanation for the major changes in raw materials and tempers listed above is the diverse geographical location and settlement strategies of Mesolithic compared to Neolithic sites in the Sudanese Nile Valley. Mesolithic sites are usually located on Precambrian terraces (hence, the alkali feldspar, mica, and 


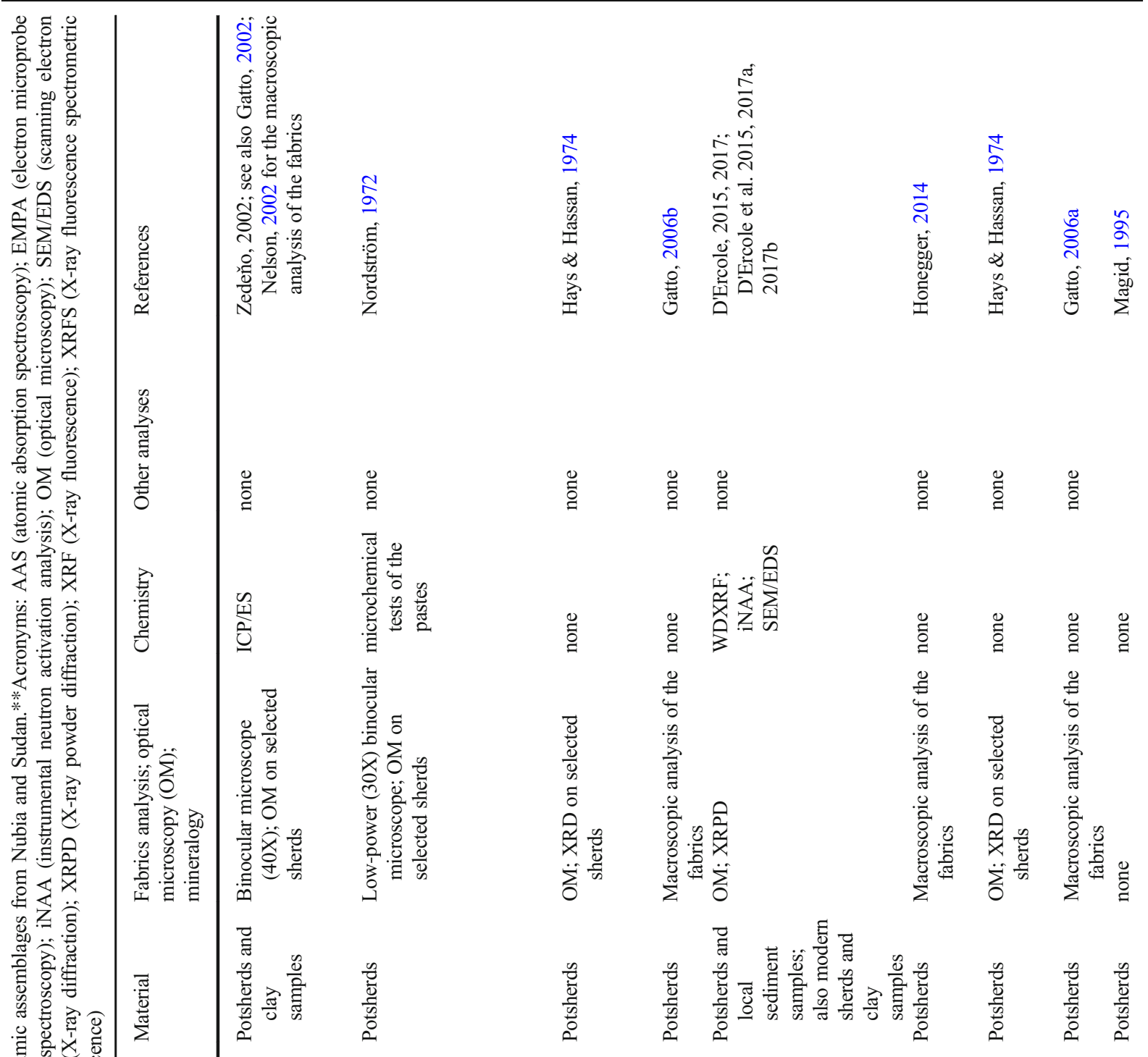

责这苛之

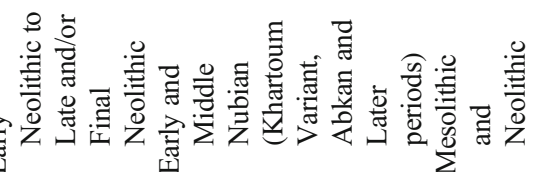

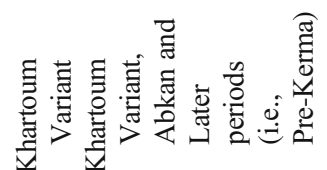

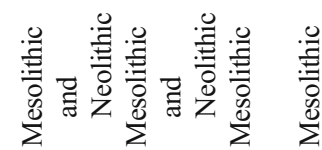

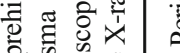

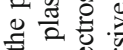

वे के क्षे

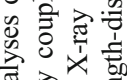

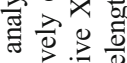

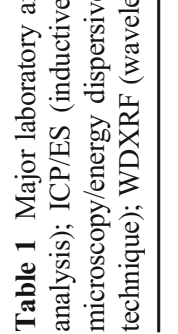

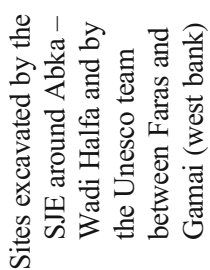

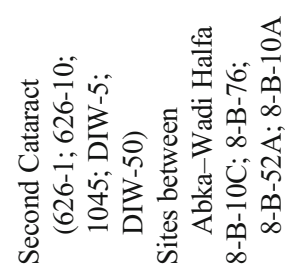

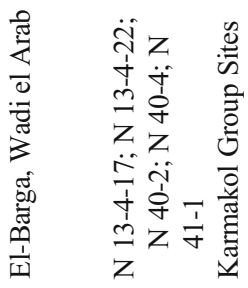

苛

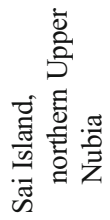

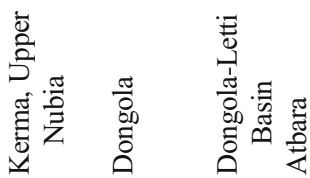




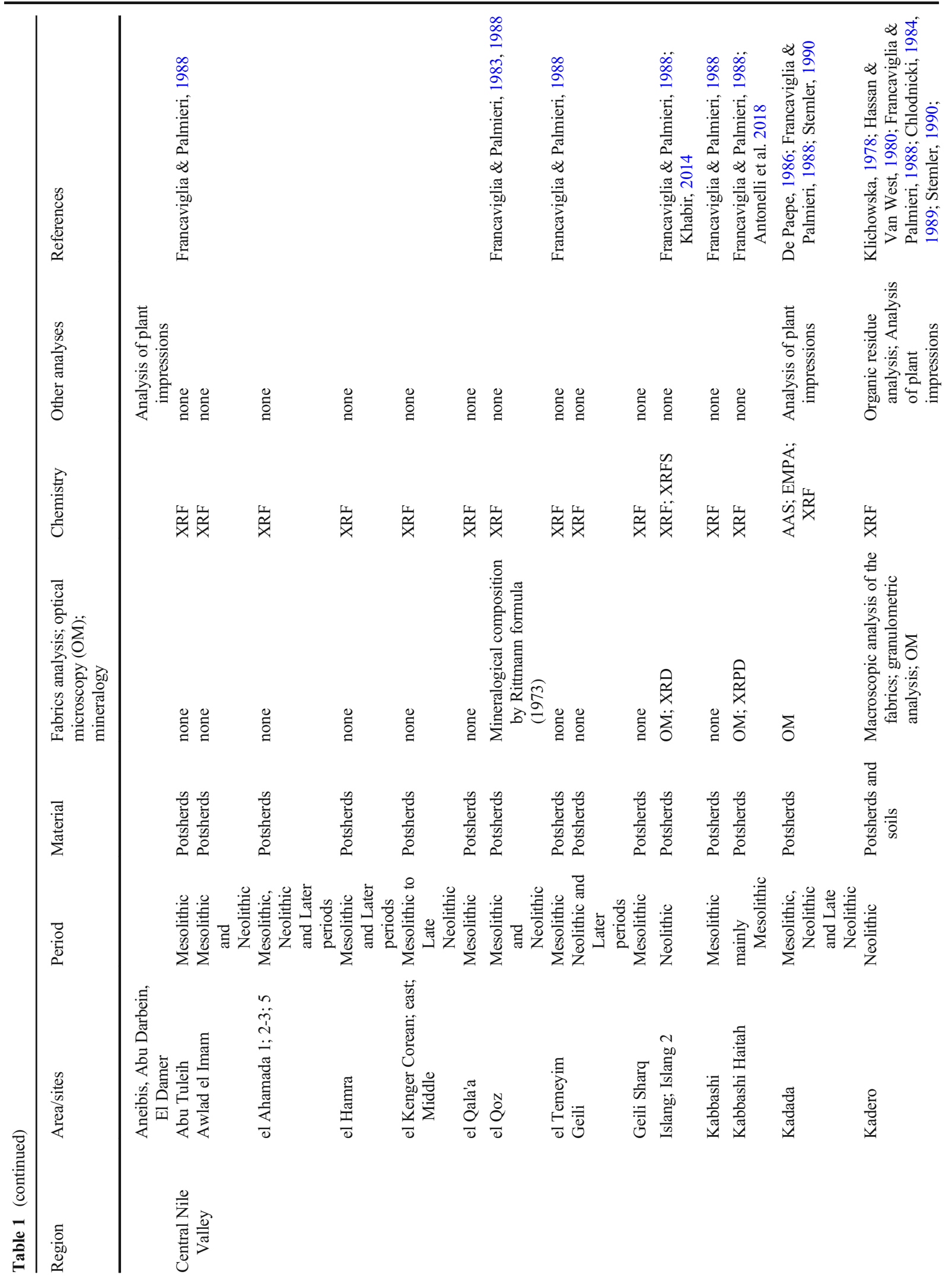




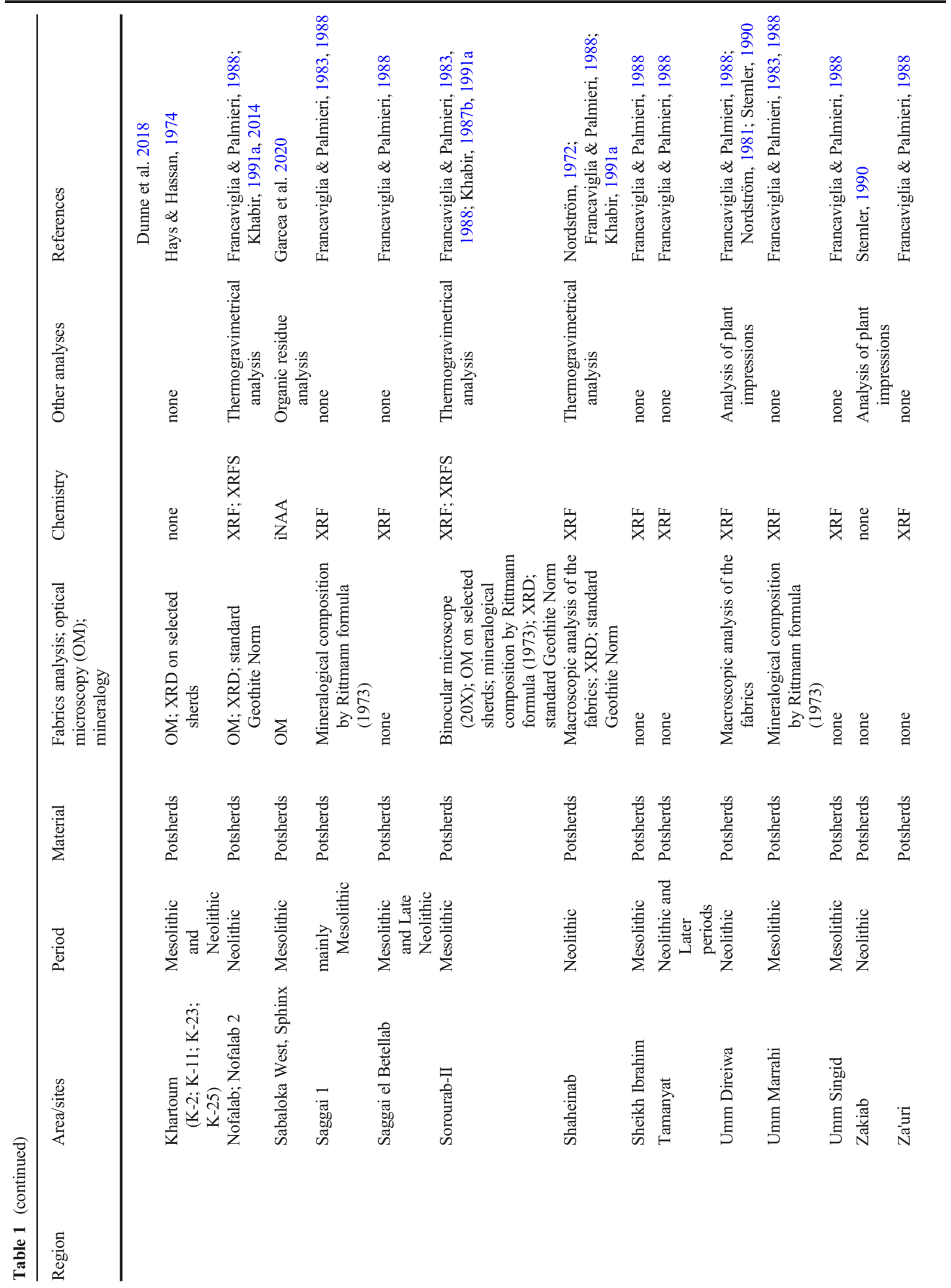




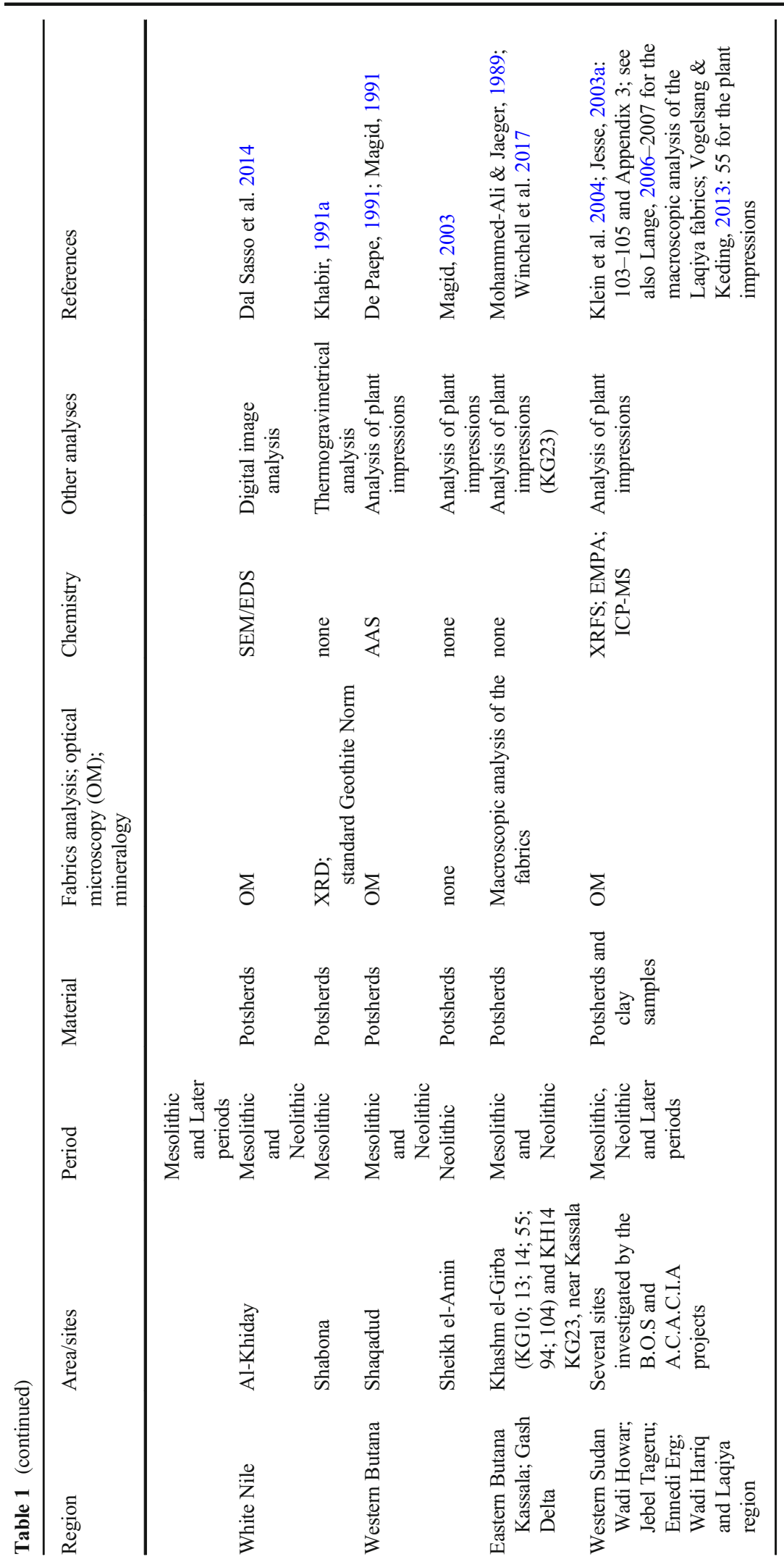




\begin{tabular}{|c|c|c|}
\hline Manufacturing sequence & Questions & Methods \& Analyses \\
\hline Discard & What? How? & $\begin{array}{l}\text { Spatial and Post depositional analysis, } \\
\text { Ethnography and Ethnoarchaeology }\end{array}$ \\
\hline Use & For What? When? & $\begin{array}{l}\text { Morphometric, Organic residue analysis, } \\
\text { Dating, Ethnography and Ethnoarchaeology }\end{array}$ \\
\hline Finishing & \multirow{2}{*}{ How? } & \multirow{2}{*}{$\begin{array}{l}\text { Petrography, Mineralogy, } \\
\text { Typological and Stylistic analysis, } \\
\text { Ethnography and Ethnoarchaeology }\end{array}$} \\
\hline Production & & \\
\hline Preparation & How? & $\begin{array}{c}\text { Petrography, Ethnography and } \\
\text { Ethnoarchaeology }\end{array}$ \\
\hline Raw material procurement & What? Where? & $\begin{array}{l}\text { Petrography, Mineralogy, Chemistry, } \\
\text { Ethnography and Ethnoarchaeology }\end{array}$ \\
\hline
\end{tabular}

Fig. 4 Manufacturing sequence, archaeological questions, and methods commonly employed for the analysis of the ceramic artifacts (scheme by G. D'Ercole)

granitoid rocks in the pastes), while Neolithic sites are usually placed on alluvial plains. Therefore, the selection of certain raw materials rather than others was due to opportunistic reasons linked to the type of minerals and rocks mainly available in the vicinity of the sites (De Paepe 1986; Hays and Hassan 1974). However, the use of clays tempered with alkali feldspar and granitic rock fragments has been recorded during the Mesolithic period, in areas where such minerals and rocks were not locally available (e.g., Al-Khiday and El Kadada, Dal Sasso et al. 2014; De Paepe 1986). In these contexts, and possibly also in others, the use of these specific pastes would take on cultural and functional importance and involve the circulation of raw materials (namely fragments or blocks of granite from the Sabaloka igneous complex approximately $100 \mathrm{~km}$ away, or the transport of finished vessels from there (Dal Sasso et al. 2014; Usai 2016)). Interestingly, at Al-Khiday and Kabbashi Haitah, a correlation has been noticed between certain fabric groups and decorative types, pointing to an intrasite chronological variability of both technological and stylistic traits (Antonelli et al. 2018; Dal Sasso et al. 2014; Salvatori 2012).

At some sites and areas of the Nile Valley, the discontinuity in the selection and use of clay raw materials and technological choices between the Mesolithic and the Neolithic periods is remarkable (e.g., Sai Island). However, at other sites in central Sudan, technological and compositional analysis of pottery assemblages seems to indicate a greater resilience of technological choices and clay recipes from the Mesolithic through the Neolithic periods (D'Ercole, personal observation, see also differences between Neolithic pottery fabrics from eastern and western bank sites in central Sudan highlighted by Francaviglia and Palmieri 1988).

West of the Nile Valley, in the Wadi Howar region, Neolithic Leiterband-style ceramics continue to be produced in continuity with the earlier Dotted Wavy Line/ Laqiya pottery, preserving mineral-tempered pastes and the same building techniques (coiling) and surface treatments (burnished and smoothed surfaces) (Keding 2006, p. 243). For eastern Sudan, petrographic and compositional information is based mainly on macroscopic descriptions. Early Mesolithic ceramics of the eastern Butana region (Pre-Saroba pottery: second half of the 6th millennium BC), which are mainly decorated with horizontal wavy line motifs on unburnished wares, show two kinds of mineral-tempered fabrics. The first includes a coarse texture, while the second presents a finer texture. The pottery of the following Saroba phase, decorated with dotted straight lines and dotted zigzags, is still characterized by unburnished surfaces and mineral (sand) tempered fabrics (Mohammed-Ali and Jaeger 1989, pp. 474-476). Differently, the Neolithic Butana group ceramics (c. 3600-3100 cal BC) are vegetal tempered and contain threshing wastes, including domesticated-type sorghum plants (Manzo 2017; Winchell et al. 2017).

Combined with the greater interest in raw material procurement and technology of production, the latest trend in the study of pottery in Sudan, but also in other African regions, concerns the analysis of organic residues. In this regard, recent studies allowed (us) to extend 
the concepts of tradition and identity to the content of ceramics (e.g., Dunne et al. 2018; outside of Sudan, see Fewlass et al. 2020; Matthews and Nowotnick 2019). This potentially permits (us) to reconsider the communicative role of decorated vessels as visual markers complementing and reinforcing the technological choices to define their function and possibly also their ownership (see the development of this idea for eastern Africa by Ashley and Grillo 2015, p. 474). In this direction, the massive "Green Sahara" project proposes a radical, interdisciplinary approach, combining biomolecular and stable isotopic analysis of organic residues in prehistoric pottery to provide dietary and ecological signatures with high-resolution palaeohydrological mapping and spatio-temporal modeling of ecological and archaeological data (www.greensaharaleverhulme.com). In Sudan, organic residue analysis has recently provided excellent results for understanding the functions of the vessels, which enriches the picture of the knowledge achieved so far on the important topic of pottery use and foodways (Dunne et al. 2012, 2016, 2018). However, this type of analysis presents some limits since it only allows the identification of the latest use of a vessel. The early Holocene ceramics possibly had different functions and were related to various social activities that included storing, cooking, processing, and preparing food (Haaland 2007). During the Neolithic period, ceramic manufacturing intensified, and vases increasingly covered a wider range of functions with differences between domestic and funerary productions.

\section{The Case Study of Sai Island: Continuity and Discontinuity in the Chaînes Operatoires of Nubian Pottery}

The present author carried out an integrated stylistic, technological, and compositional analysis of the ceramic manufacturing traditions from Sai Island (northern Upper Nubia), dating to the early, middle, and late Holocene periods (D'Ercole 2017; D'Ercole et al. 2015; D'Ercole et al. 2017a). Furthermore, a longue durée analysis of the Nubian ceramic assemblages from prehistoric times to the Kerma and New Kingdom periods ( 3 rd to 2 nd millennium $\mathrm{BC}$ ) was carried out within the framework of the ERC project "AcrossBorders" (D'Ercole et al. 2017b). These studies were theoretically inspired by research based on the chaine opératoire approach (see among others Gosselain 2008; Roux 2016; Roux and Courty 2013). The analysis of pottery was planned in two phases, and the archaeometric laboratory methods were preceded by a visual stylistic and technological assessment of the ceramic corpus, based on Caneva's classification system, and combined with the relational database designed by Garcea (2005).

Over 3,000 potsherds from four sites were studied for macroscopic classification. Together with ceramics, local sediments taken from the stratigraphic deposits of the sites were also included in the analysis. The main purpose was to diachronically reconstruct the manufacturing sequences of ceramic production among the inhabitants of Sai Island from the eighth to the third millennium $\mathrm{BC}$, with reference to the ceramic complexes belonging to the local Khartoum Variant, Abkan, and other Pre-Kerma horizons.

The Sai Khartoum Variant ceramics were made of clays rich in alkali feldspar and fragments of granitic and/or metamorphic rocks taken from the local Precambrian outcrops (D'Ercole 2017) (Fig. 5a). A few Khartoum Variant potsherds contained mainly monocrystalline rounded quartz (D’Ercole 2017, p. 109). An important break in the technology of production was recognized at the transition from the Khartoum Variant to the Abkan horizon (c. 5500 BC), with a change from the use of coarse alkali feldspar and quartz-rich clays to the selection of Nile alluvial clays containing fine quartz, plagioclase, volcanic rock fragments, and heavy minerals (Fig. 5b). Chemically, the Khartoum Variant pottery from Sai is richer in potassium $(\mathrm{K})$, rubidium $(\mathrm{Rb})$, and zirconium ( $\mathrm{Zr}$ ), which are contained in the alkali feldspar and local pegmatites. Conversely, the Abkan pottery at Sai includes higher amounts of scandium (Sc), chromium $(\mathrm{Cr})$, and iron $(\mathrm{Fe})$, all elements related to either the clay matrix and/or to the heavy minerals, which are detrital components of the Holocene Nile alluvia (D'Ercole 2017; D'Ercole et al. 2017b).

Starting with the Abkan horizon, a major change in the clay preparation process (from mineral-tempered to organic-tempered pastes) and manufacturing techniques (reduction in the thickness of vessel walls, and the disappearance of certain techniques and decorative motifs) was also observed (D’Ercole 2017, p. 154). A substantial continuity in the technological features of pottery characterized the following horizons for several millennia, and only the stylistic and morphological traits significantly changed (D'Ercole et al. 2017b). The study demonstrates that stylistic developments in pottery 


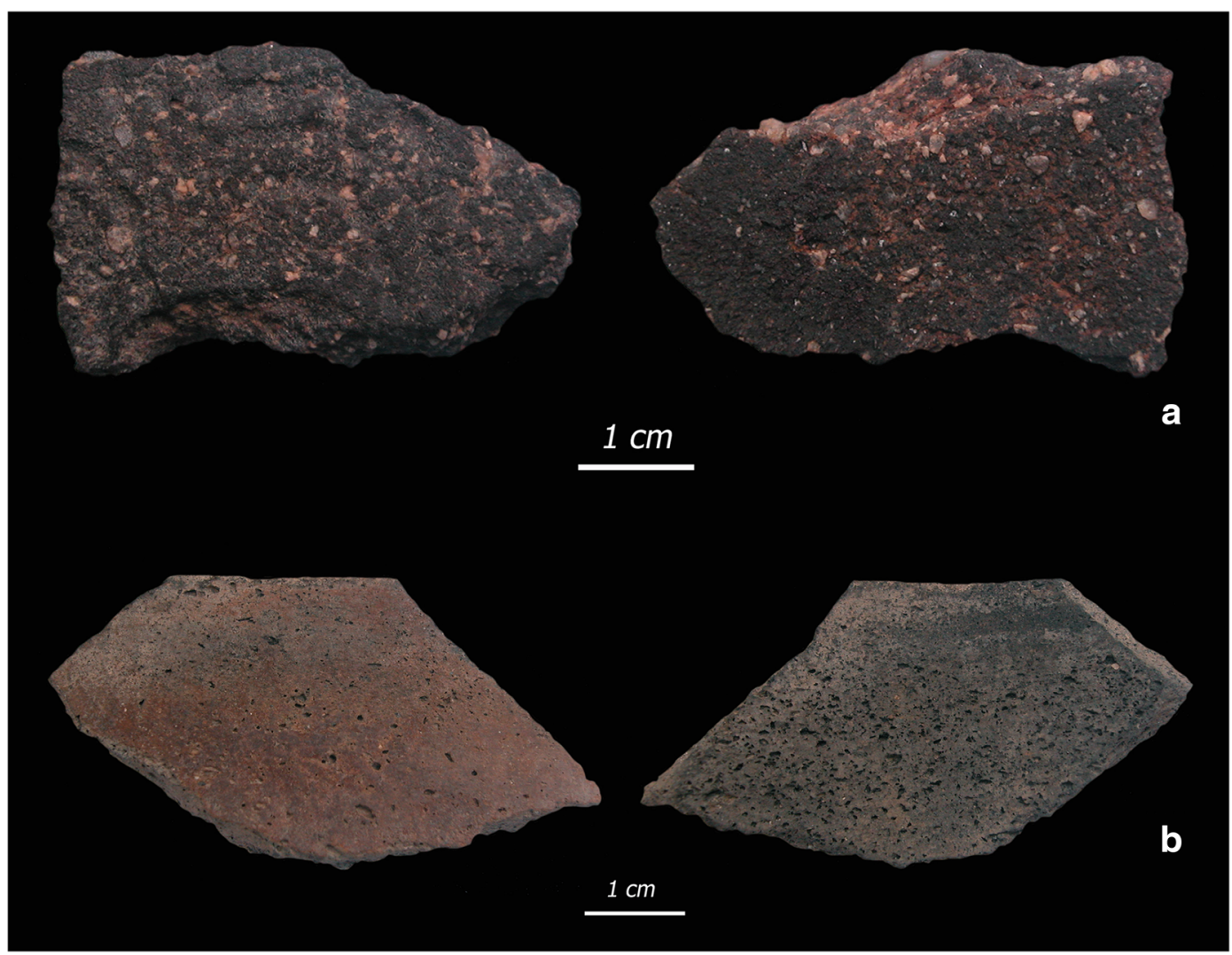

Fig. 5 Khartoum Variant (a) and Abkan (b) potsherds from Sai Island (photos by N. Trotti)

manufacturing did not result from technological innovation (e.g., diverse raw materials and tempers, manufacturing techniques, surface treatments and/or firing technique). In fact, decorative styles changed faster than technological styles (sensu Lechtmann 1977). Decorative styles are essentially exterior features and, therefore, an easily imitable trait of an artifact, while technology is a much more resilient aspect, with a higher propensity for continuity (Gosselain 2000; Roux 2008; Roux and Courty 2013). Roux (2008, p. 87) distinguished between continuous and discontinuous changes. Thus, "a continuous change is characterised by new performances only, or the evolution or diversification of technological components...A discontinuous change implies the development of new competencies or techniques, and it marks a break with the tradition."

The results from the analysis of pottery assemblages from Sai fit in the general picture observed at environmental, cultural, and economic levels across Nubia. The most significant discontinuity in ceramic technology coincided with climate change in the mid-Holocene. In this period, a series of significant changes affected the local landscape, and these also affected how human groups perceived the landscape. Furthermore, new economic strategies entailed a different use of the land, and novel dynamics of relationships were built between humans, animals, and the environment. For example, during the mid-Holocene, the Abkan people adopted livestock. Consequently, foodways and traditions changed, and with them the social significance and the function of the pots (D'Ercole 2017, p. 172).

\section{Connecting Macroscopic Data and Laboratory Analyses}

For over seventy years, theoretical approaches and methods of classification of ceramic objects in Sudan have gradually changed, as have the perspectives and the general purposes of archaeological research. In general, scholarly attention has progressively shifted from forms (i.e., decoration and shape) to mineral and chemical compositions of ceramics and vessel contents (i.e., petrographic, compositional, and organic residue 
analyses). Nevertheless, the analysis of decorative motifs and techniques continues to play an essential role in the study of cultural spatio-temporal dynamics. Hence, a crucial issue in the interpretation of ceramic data concerns the interconnection between the information obtained from typologies and styles of vessels and the information relating to the technology of production, composition, and use. The results of petrographic and chemical analyses of ceramic assemblages supported most of the decorative changes observed based on the typologies of pottery. This is especially true for the Nubian and Sudanese Nile Valley, but one cannot extend this reasoning to the regions east and west of the Nile.

Along the Nile, both in northern and in central Sudan, the most significant technological innovations in ceramic production started during the mid-Holocene, in concurrence with the beginning of the Neolithic period and the adoption of a food-producing economy. During this period, most of the typical former decorative traditions (i.e., the wavy line and the rocker stamped dotted wavy line decorations) were discontinued. This phenomenon occurred in different moments but covered a large geographical area. At Sai Island, this scenario was tentatively interpreted as a break in a pattern of phylogenetic continuity (sensu Roux and Courty 2013) corresponding to a gradual replacement in population at the transition from the Khartoum Variant to the Abkan period (D'Ercole 2017, p. 172). This hypothesis, in order to be validated or discarded, would require further diagnostic analyses of the material remains and also a robust study of human remains. In the region of Kerma, Jakob and Honegger (2017, p. 48) interpreted change based on "the arrival of new populations in the early $6^{\text {th }}$ millennium BC, which merged with the Mesolithic substratum, bringing about progressive changes in the material culture and more marked contrasts in the area of funerary rituals."

Concerning central Sudan, Caneva (1991) suggested, based on formal ceramic morphology (i.e., shapes, ware, surface treatment, and decorations), a connection between the Sahara and the Nile Valley. Specifically, she proposed an earlier appearance of the short DWL in the central Sahara than in central Sudan. This hypothesis is currently criticized by Salvatori (2012) and Brass et al. (2018). A review of the ceramic evidence from the Wadi Howar region, a strategic contact area between the Sahara and the Nile Valley, revealed the absence of the dotted wavy line ceramic motif of the small wave type among the Early Khartoum assemblage. In contrast, there is the presence of the "Nilotic" dotted wavy line with long waves and of the incised wavy line. Based on this evidence, Jesse (2004, p. 305) argued that "the Wadi Howar can thus not be regarded as a link between the Nile Valley and the more central parts of the Sahara with regard to the spread of Incised Wavy Line patterns or the spread of Dotted Wavy Line patterns with small waves."

To date, it is still doubtful whether, at the transition from the Mesolithic to the Neolithic period, the pottery of central Sudan received some of its new traits from the Sahara or vice versa. According to Caneva (1991, 1993; Caneva and Marks, 1990), this change would have happened at the end of the Mesolithic in concurrence with a partial abandonment of the Sahara. Also, it is still unclear whether the introduction and spread of the new Neolithic ceramic types and manufacturing techniques occurred via a tangible migration of people or through more complex and subtle cultural learning and transmission processes or possibly as the combination of both of these factors. A closely related topic concerns the timing and routes of animal domestication (for an overview on this, see Garcea 2020, chapter 5).

Archaeometric data on ceramic pastes alone do not allow us to answer these questions. The selection of raw materials and tempers, as well as other technological choices in the manufacturing process, may just respond to transient and opportunistic factors which are contingent to the context of production and use of vessels. Nevertheless, technological information on the production process, if properly related to visual decorative data, may improve the inferences we can draw from ceramics and permit us to better understand human traditions, communication codes, and interrelationship with the external environment. In general, decorative and raw material data should be combined in ceramic analysis, because the cultural orbits of ceramic decorative motifs do not always coincide with those of the procurement of raw materials and technological traditions. Likewise, a spatial representation of ceramic traditions based only on the use of raw materials and tempers can sometimes only provide insights into the geology of the territory.

At Sai Island, the major shift (both in the technological and decorative codes of pottery) occurred in the Abkan horizon. However, during the transition from the Abkan to Pre-Kerma horizon, only the decorative code changed, while the technological code remained almost unaltered. Outside the Nile Valley, in the Wadi Howar region, local trends in the ceramic sequence 
show a continuity of technological attributes between the Dotted Wavy Line/Laqiya (c. 5200-4000 BC) and the Leiterband horizons (c. 4000-2200 BC), but with differences in decorative motifs and vessel types. A major transformation in both decorative and technological styles occurred later, during the Handessi horizon (c. 2200-1100 BC), at the transition from cattle- to small livestock-keeping (Keding 2006, p. 255).

Another important issue in the reading of the archaeometric results concerns the quality of the raw data and the way they are communicated and interpreted. In Sudan, interests in ceramic technology seem to have begun earlier than other regions of Africa. A significant number of studies on raw materials and fabrics were initiated in the 1970s. However, most of these pioneering works often provided no more than petrographic descriptions or quantitative lists of minerals and chemical elements to support typological analyses. Overall, these compositional studies of ceramics were not connected to the interpretation of the sociocultural, technological, and ecological processes.

\section{Conclusions}

Since the first definition of "Wavy Line culture" formulated by Anthony Arkell in 1949, the study of the prehistoric cultures of Sudan has been deeply entangled with that of its ceramic complexes. From the very beginning of archaeological research in the region, ceramic evidence served to define a chronological and spatial frame for understanding the distribution and developments of human cultures. Thus, the emergence and spread of certain decorations-i.e., the incised wavy line and impressed dotted wavy line - as temporal and spatial markers, were largely employed to determine site chronologies, group identities, and circulation of people. In Sudanese archaeological literature, the themes associated with ceramic analysis are traditions, changes, identities, cultural spheres, transformations, communications, and, recently, encounters, complexity, and hybridization. Common to all these themes is the foundational idea of ceramics as objects that, on the one hand, define social and cultural individualities, establishing figurative, geographical, chronological, and/or cultural boundaries. On the other hand is the idea that ceramics favor communication and are implicated in the encounter between different cultural groups, and sociopolitical entities. Above all, through ceramics, humans build relationships with other humans, animals, and eventually with the landscape.

The classification scheme developed by Isabella Caneva in the 1980s mainly addressed the observation and analysis of ceramic decoration techniques and motifs, creating a system of classification that, albeit with its limits, is unbiased and above all free from any implication of ethnicity or geographical identity. This represents a relatively early and extraordinary achievement in the archaeology of Sudan. A further merit of Caneva's classification is that it is an "open system," which can be supplemented with other variables and virtually extended and adapted to other contexts. In parallel to Caneva's system, other visual approaches to the study of decorations developed. However, the variety of methods currently in use has not substantially changed the interpretation of data in terms of general cultural sequences and chronologies. Rather, the progressive fine-tuning of the ways and techniques of classification of the formal and stylistic attributes of the vessel, and the local variations found within the standards of Caneva's scheme, led to a more attentive and conscious reading of the Sudanese prehistoric ceramic complexes and, through them, of human cultural processes. The introduction of the chaine opératoire approach to ceramic analysis in West and Central Africa has provided a more comprehensive perspective that leads to the understanding of the environmental setting, resources, and means and technologies of production. Furthermore, since the 1970s, the provenance and technological studies of pottery have intersected with the typological classifications of ceramics. A dichotomy between the stylistic and the laboratory data can no longer be recognized in several publications on Sudanese prehistory (e.g., Dal Sasso et al. 2014; Garcea et al. 2020). In this regard, the archaeometric analysis of pottery, even where it leads to divergent conclusions from the typological classification, has mainly worked like a magnifying glass emphasizing the information embedded in the ceramic record, and how this can better inform us about the local dynamics and the relationships between human groups and their specific landscape.

Lately, the archaeology of the Sudan has been moving away from its main setting along the Nile Valley to incorporate the biographies of more peripheral regions and sites located in marginal and very fragile areas like the current Nubian and Libyan deserts and the "frontier zones" of the Eastern and Southern Sudan (e.g., Brass 
2019; Edwards 2019; Manzo 2017). Furthermore, there is greater sensitivity to understanding contact-space dynamics between different human groups and between them and the surrounding landscape (see Budka 2020). The progress made in the field of archaeometry, microarchaeology, and food archaeology, together with a greater awareness of the chronological sequences and climatic, economic, and cultural transformations, will hopefully continue to expand our understanding of the relations and encounters between the different groups of hunter-gatherers, pastoralists, and farmers in Sudan and the adjacent regions.

Acknowledgements I sincerely thank Elena Garcea for passing on her knowledge and passion for Sudanese prehistory and ceramics to me. I consider myself extremely lucky to have had the privilege of working continuously in Sudan since 2009 at wonderful sites such as Sai Island and Sabaloka West. For this, I am grateful to the Mission Archéologique de l'Ile de Saï and the Charles University Sabaloka Expedition for welcoming me as a team member and to the National Corporation for Antiquities and Museums (NCAM) in Khartoum, its former and current directors, and the inspectors who have accompanied and assisted us in Sai and Sabaloka. I am especially thankful to Julia Budka, who, in 2013, gave me an exceptional chance to be part of the team of her ERC starting grant project "AcrossBorders" (Grant agreement no. 313668 ) and, again in 2020, to join her ERC consolidator project "Diverse Nile" (Grant agreement no. 865463). I deeply thank her for the experiences shared on the field and what she taught me about Sudanese archaeology. I kindly acknowledge her, Elena Garcea, Lenka Varadzinová, and Ladislav Varadzin, for their contributions to improving this article. A special thank you also goes to my colleague, Rennan Lemos, for his careful review and helpful comments. Finally, I thank the anonymous referees for their positive criticism and many inputs to an earlier version of this paper.

Funding Open Access funding enabled and organized by Projekt DEAL.

\section{Declarations}

Conflict of Interest The author declares no competing interests.

Open Access This article is licensed under a Creative Commons Attribution 4.0 International License, which permits use, sharing, adaptation, distribution and reproduction in any medium or format, as long as you give appropriate credit to the original author(s) and the source, provide a link to the Creative Commons licence, and indicate if changes were made. The images or other third party material in this article are included in the article's Creative Commons licence, unless indicated otherwise in a credit line to the material. If material is not included in the article's Creative Commons licence and your intended use is not permitted by statutory regulation or exceeds the permitted use, you will need to obtain permission directly from the copyright holder. To view a copy of this licence, visit http://creativecommons.org/licenses/by/4.0/.

\section{References}

Adams, W. Y. (2007). A century of archaeological salvage, 19072007. Sudan and Nubia, 11, 48-56.

Addison, F. (1949). Jebel Moya. Oxford: Oxford University Press.

Antonelli, F., Lazzarini, L., Caneva, I., and Maritan, L. (2018). Pottery production at the Mesolithic site of Kabbashi Haitah (Central Sudan): An integrated morphological, petrographic and mineralogical analysis. Mediterranean Archaeology and Archaeometry, 18, 51-15.

Arkell, A. J. (1949). Early Khartoum: An account of the excavation of an early occupation site carried out by the Sudan Government Antiquities Service in 1944-5. Oxford: Oxford University Press.

Arkell, A. J. (1953). Shaheinab: an account of the excavation of a Neolithic occupation site carried out for the Sudan Antiquities Service in 1949-50. Oxford: Oxford University Press.

Arkell, A. J. (1972). Dotted wavy line pottery in African prehistory. Antiquity, 46, 221-222.

Ashley, C. Z. (2010). Towards a socialised archaeology of ceramics in Great Lakes Africa. African Archaeological Review, 27, 135-163.

Ashley, C. Z., and Grillo, K. M. (2015). Archaeological ceramics from eastern Africa: Past approaches and future directions. Azania: Archaeological Research in Africa, 50(4), 460-480.

Bailloud, G. (1969). L'évolution des styles céramiques au Ennedi (République du Tchad). In J. P. Lebeuf (Ed.), Actes du 1er Colloque international d'Archéologie Africaine (Fort Lamy 1966) (pp. 31-45) Fort Lamy.

Baldi, J., and Roux, V. (2016). The innovation of the potter's wheel: A comparative perspective between Mesopotamia and the southern Levant. Levant, 48(3), 236-253.

Brass, M. (2016). Reinterpreting chronology and society at the mortuary complex of Jebel Moya (Sudan). Oxford: Archaeopress.

Brass, M. (2019). Introduction. Beyond the Nile: New archaeological research in Sudan and South Sudan. Azania, 54(4), 421-424.

Brass, M., and Schwenniger, J.-L. (2013). Jebel Moya (Sudan): New dates from a mortuary complex at the southern Meroitic frontier. Azania, 48, 455-472.

Brass, M., Adam, A. H. A., and Wellings, J. (2018). New data from Jebel Moya and Shaqadud (central Sudan): Implications for Late Mesolithic interconnectivity with the Sahara. Libyan Studies, 49, 21-49.

Braun, D. P. (1983). Pots as tools. In J. A. Moore and A. S. Keene (Eds.), Archaeological hammers and theories (pp. 107-134). New York: Academic Press.

Budka, J. (2020). Cultural diversity in the Middle Nile: New approaches towards "contact space biographies". The Project Repository Journal, 4, 20-23.

Camps-Fabrer, H. (1966). Sur quelques techniques décoratives de la céramique impressionnée saharienne. In Congrès 
Préhistorique de France. Compte rendu de la XVIIIe session, Ajaccio 4-14 avril 1966 (pp. 143-154). Paris.

Caneva, I. (1983). 'Wavy Line' decoration from Saggai I: An essay of classification. In I. Caneva (Ed.), Pottery-using gatherers and hunters at Saggai (Sudan): Preconditions for food production (pp. 155-190). Origini, 12. Roma: Gangemi Ed.

Caneva, I. (1987). Pottery decoration in prehistoric Sahara and Upper Nile: A new perspective. In B. E. Barich (Ed.), Archaeology and environment in the Libyan Sahara. The excavations in the Tadrart Acacus, 1978-1983 (pp. 231254). Oxford: BAR International Series 368.

Caneva, I. (Ed.). (1988). El Geili: The history of a Middle Nile environment 7000 B.C.-A.D. 1500, British Archaeological Reports (Vol. 424). Oxford: Archaeopress.

Caneva, I. (1989). Typological notes: The Sudanese case. In L. Krzyżaniak and M. Kobusiewicz (Eds.), Late prehistory of the Nile Basin and the Sahara, Studies in African Archaeology, 2 (pp. 375-379). Poznań: Poznań Archaeological Museum.

Caneva, I. (1991). Jebel Moya revisited: A settlement of the 5th millennium $\mathrm{BC}$ in the Middle Nile Basin. Antiquity, 65, 262-268.

Caneva, I. (1993). Pre-pastoral Middle Nile: Local developments and Saharan contacts. In L. Krzyzaniak, M. Kobusiewicz, and J. Alexander (Eds.), Environmental Change and Human Culture in the Nile Basin and Northern Africa until the Second Millennium BC, Studies in African Archaeology, 4 (pp. 405-411). Poznań: Poznań Archaeological Museum.

Caneva, I. (1996). The influence of Saharan prehistoric cultures on the Nile valley. In G. Aumassip, J. D. Clark, and F. Mori (Eds.), The prehistory of Africa, XIII Congress UISPP, Colloquia (Vol. 15, pp. 231-239). ABACO.

Caneva, I., and Marks, A. E. (1990). More on the Shaqadud pottery: Evidence for Saharo-Nilotic connections during the 6th-4th millennium B.C. Archéologie du Nil Moyen, 4, 1135.

Caneva, I., and Zarattini, A. (1983). Microlithism and functionality in the Saggai 1 industry. In I. Caneva (Ed.), Pottery using gatherers and hunters at Saggai (Sudan). Preconditions for food production (pp. 209-233). Origini, 12. Roma: Gangemi Ed.

Caneva, I., Garcea, E. A. A., Gautier, A., and Van Neer, W. (1993). Pre-pastoral cultures along the Central Sudanese Nile. Quaternaria Nova, 3, 177-252.

Casanova, E., Knowles, T. D. J., Bayliss, A., et al. (2020). Accurate compound-specific ${ }^{14} \mathrm{C}$ dating of archaeological pottery vessels. Nature, 580, 506-510.

Caton-Thompson, G. (1931). The Zimbabwe culture. London: Clarendon Press.

Chlodnicki, M. (1984). Pottery from the Neolithic settlement at Kadero. In L. Krzyzaniak and M. Kobusiewicz (Eds.), Origin and early development of food-producing cultures in NorthEastern Africa, 1 (pp. 337-342). Poznań: Poznán Archaeological Museum.

Chlodnicki, M. (1989). The petrographic analyses of the Neolithic pottery of Central Sudan. In L. Krzyzaniak and M. Kobusiewicz (Eds.), Late prehistory of the Nile Basin and the Sahara: Studies in African archaeology, 2 (pp. 369-373). Poznań: Poznán Archaeological Museum.
Chlodnicki, M., Kobusiewicz, M., and Kroeper, K. (Eds.). (2011). Kadero: The Lech Krzyzaniak excavations in the Sudan. Poznań: Poznan Archaeological Museum.

Clark, J. D. (1989). Shabona: An early Khartoum settlement on the White Nile. In L. Krzyzaniak and M. Kobusiewicz (Eds.), Late Prehistory of the Nile Basin and the Sahara: Studies in African archaeology, 2 (pp. 387-410). Poznań: Poznań Archaeological Museum.

Close, A. E. (1995). Few and far between: Early ceramics in North Africa. In W. K. Barnett and J. W. Hoopes (Eds.), The emergence of pottery: Technology and innovation in Ancient Societies (23-37). Washington, D.C.: Smithsonian Institution Press.

Crossland, L. B., and Posnansky, M. (1978). Pottery, people and trade at Begho. In I. Hodder (Ed.), The Spatial Organisation of Culture (pp. 77-89). London: Duckworth.

D'Ercole, G. (2017). Ceramic manufacturing techniques and cultural traditions in Nubia from the 8th to the 3rd millennium BC. Examples from Sai Island. Oxford: Archaeopress.

D’Ercole, G., Eramo, G., Garcea, E. A. A., Muntoni, I. M., and Smith, J. R. (2015). Raw material and technological changes in ceramic productions at Sai Island, northern Sudan from the 7 th to the 3rd millennium BC. Archaeometry, 57(4), 597-616.

D’Ercole, G., Garcea, E. A. A., Eramo, G., and Muntoni, I. M. (2017a). Variability and continuity of ceramic manufacturing of prehistoric pottery from Upper Nubia, Sudan: An ethnographic comparison. Journal of Archaeological Science: Reports, 16, 553-563.

D’Ercole, G., Budka, J., Sterba, J. H., Garcea, E. A. A., and Mader, D. (2017b). The successful 'recipe' for a longlasting tradition: Nubian ceramic assemblages from Sai Island (northern Sudan) from prehistory to the new Kingdom. Antiquity, 91, $24-42$.

Dal Sasso, G., Maritan, L., Salvatori, S., Mazzoli, C., and Artioli, G. (2014). Discriminating pottery production by image analysis: A case study of Mesolithic and Neolithic pottery from Al Khiday (Khartoum, Sudan). Journal of Archaeological Science, 46, 125-143.

David, R., and Salvatori, S. (2019). Ceramic production in The Middle Nile Valley, Sudan (8000 BC - 1500 AD). In C. Smith (Ed.), Encyclopedia of global archaeology. Springer. https://doi.org/10.1007/978-3-319-51726-1_3350-1.

De Paepe, P. (1986). Etude minéralogique et chimique de la céramique néolithique d'El Kadada et ses implications archéologiques. Archéologie du Nil Moyen, 1, 113-140.

De Paepe, P. (1991). Appendix A: Ceramics from Shaqadud studies by physical methods. In A. E. Marks and A. S. Mohammed (Eds.), The Late prehistory of the Eastern Sahel (pp. 261-266). Dallas: Southern Methodist University Press.

Dunne, J., Evershed, R. P., Salque, M., Cramp, L., Bruni, S., Ryan, K., Biagetti, S., and di Lernia, S. (2012). First dairying in green Saharan Africa in the fifth millennium BC. Nature, 486, 390-394.

Dunne, J., Mercuri, A. M., Evershed, R. P., Bruni, S., and di Lernia, S. (2016). Earliest direct evidence of plant processing in prehistoric Saharan pottery. Nature Plants, 3, 1-6.

Dunne, J., di Lernia, S., Chlodnicki, M., Kherbouche, F., and Evershed, R. P. (2018). Timing and pace of dairying 
inception and animal husbandry practices across Holocene North Africa. Quaternary International, 471, 147-159.

Dunnel, R. C. (1971). Systematics in prehistory. New York: Free Press.

Dunnel, R. C. (1986). Methodological issues in Americanist artifact classification. Advances in archaeological method and theory, 9, 149-207.

Edwards, D. N. (2019). Between the Nile and the Sahara: Some comparative perspectives. In M. C. Gatto, D. J. Mattingly, N. Ray, and M. Sterry (Eds.), Burials, migration and identity in the ancient Sahara and beyond (pp. 195-222). Cambridge: Cambridge University Press.

Eramo, G., Muntoni, I. M., Aprile, A., Pallara, M., Rotunno, R., Zerboni, A., and Di Lernia, S. (2020). Networking through pottery characterisation at Takarkori rock shelter (Libyan Sahara, 10,200-4650 cal BP). Archaeological and anthropological science, 12(220). https://doi.org/10.1007/s12520020-01118-x.

Fattovich, R. (1989). The late prehistory of the Gash Delta. In L. Krzyzaniak and M. Kobusiewicz (Eds.), Late Prehistory of the Nile Basin and the Sahara (pp. 481-498). Poznań: Poznan Archaeological Museum.

Fattovich, R., Marks, A. E., and Mohammed-Ali, A. (1984). The archaeology of the Eastern Sahel, Sudan: Preliminary results. African Archaeological Review, 2, 173-188.

Fernandez, V. M., Jimeno, A., and Menendez, M. (2003). Archaeological excavations in prehistoric sites of the Blue Nile area, Central Sudan. Complutum, 14, 201-272.

Fewlass, H., Mitchell, P. J., Casanova, E., and Cramp, L. J. E. (2020). Chemical evidence of dairying by hunter-gatherers in highland Lesotho in the late first millennium ad. Nature Human Behaviour, 4, 791-799. https://doi.org/10.1038 /s41562-020-0859-0.

Florenzano, A., Mercuri, A. M., Altunoz, M., and Garcea, E. A. A. (2016). Pollen evidence of cultural and environmental connections in Sudanese Nubia during the Early and Middle Holocene. Quaternary International, 412(Part B), 65-80.

Francaviglia, V., and Palmieri, A. M. (1983). Petrochemical analyses of the 'Early Khartoum' pottery. A preliminary report. In I. Caneva (Ed.), Pottery-using gatherers and hunters at Saggai (Sudan). Preconditions for Food Production (pp. 191-205). Origini, 12. Roma: Gangemi Ed.

Francaviglia, V., and Palmieri, A. M. (1988). Ceramic fabrics and source locations in the Khartoum Province. In I. Caneva (Ed.) El Geili: The History of a Middle Nile Environment 7000 B.C.-A.D. 1500 (pp. 345-358). BAR International Series 424. Oxford: Archaeopress.

Gallay, A. (1970). La poterie en pays Sarakolé (Mali, Afrique Occidentale). Journal des Africanistes, 40, 7-84.

Gallin, A. (2002). Proposition d'une étude stylistique de la céramique imprimée de Kobadi: Défnition de classes morphométriques des vases et analyse de la composition de leurs décors. Préhistoire Anthropologie Méditerranéennes, 10-11, 117-134.

Garcea, E. A. A. (2001). Uan Tabu in the Settlement History of the Libyan Sahara. In Arid Zone Archaeology Monographs 1. Firenze: Edizioni All'Insegna del Giglio.

Garcea, E. A. A. (2005). Comparing chaînes opératoires: Technological, cultural and chronological features of prepastoral and pastoral ceramic and lithic productions. In A. Livingstone Smith, D. Bosquet, \& R. Martineau (Eds.),
Pottery manufacturing processes: Reconstitution and interpretation (pp. 215-228). Oxford: Archaeopress.

Garcea, E. A. A. (2006a). Pottery making processes at Esh Shaheinab, Sudan. In K. Kroeper, M. Chłodnicki, and M. Kobusiewicz (Eds.), Archaeology of early Northeastern Africa (pp. 99-112). Poznań: Poznań Archaeological Museum.

Garcea, E. A. A. (2006b). The endless glory of a site: eshShaheinab in the Sudanese prehistory. In I. Caneva and A. Roccati (Eds.), Proceedings of the X International Conference of Nubian Studies, Rome 9-14 September 2002 (pp. 95-102). Rome: Acta Nubica.

Garcea, E. A. A. (2008). The ceramics from Adrar Bous and surroundings. In J. D. Clark and D. Gifford-Gonzalez (Eds.), Adrar Bous: Archaeology of a Central Saharan granitic ring complex in Niger (pp. 245-289). Tervuren: Royal Museum for Central Africa.

Garcea, E. A. A. (2012). Pottery manufactures at Sai Island, Sudan. In J. Kabaciński, M. Chłodnicki, and M. Kobusiewicz (Eds.), Prehistory of Northeastern Africa: New Ideas and Discoveries. Studies in African Archaeology, 11 (pp. 153-166). Poznań: Poznań Archaeological Museum.

Garcea, E. A. A. (2013). Manufacturing technology of the ceramic assemblage. In E. A. A. Garcea (Ed.), Gobero: The NoReturn Frontier. Archaeology and Landscape at the Saharo-Sahelian Borderland. Journal of African Archaeology Monograph Series, 9 (pp. 209-240). Africa Magna Verlag.

Garcea, E. A. A. (2016). Semi-permanent foragers in North Africa - an archaeological perspective. In T. Tvedt and T. Oestigaard (Eds.), A history of water, Series 3, Water and food from hunter-gatherers to global production in Africa (Vol. 3, pp. 29-54). London: I.B. Tauris.

Garcea, E. A. A. (2020). The prehistory of the Sudan. Cham: Springer.

Garcea, E. A. A., and Caputo, A. (2004). Outils statistiques pour l'étude de la production et de l'utilisation de la céramique au Sahara et au Soudan. Préhistoire Anthropologie Méditerranéennes, 13, 87-96.

Garcea, E. A. A., and Hildebrand, E. A. (2009). Shifting social networks along the Nile: Middle Holocene ceramic assemblages from Sai Island, Sudan. Journal of Anthropological Archaeology, 28, 304-322.

Garcea, E. A. A., Wang, H., and Chaix, L. (2016). High-precision radiocarbon dating application to multi-proxy organic materials from late foraging to early pastoral sites in Upper Nubia, Sudan. Journal of African Archaeology, 14(1), 83-98.

Garcea, E. A. A., D'Ercole, G., Sterba, J. H., et al. (2020). Technological variability in foragers' pottery productions at the early-mid Holocene site of Sphinx, western bank of Jebel Sabaloka (Sudan). Quaternary International. https://doi. org/10.1016/j.quaint.2020.01.020.

Gatto, M. C. (2002). Early Neolithic pottery of the Nabta-Kiseiba area: stylistic attributes and regional relationships. In I. K. Nelson and Associates (Eds.), Holocene settlements of the Egyptian Sahara. Vol. 2: The pottery of Nabta Playa (pp. 6578). New York: Kluwer Academic/Plenum.

Gatto, M. C. (2006a). The most ancient pottery from the Dongola Reach (Northern Sudan): New data from the SFDAS survey 
related to the construction of the Merowe dam. Archéologie du Nil Moyen, 10, 73-86.

Gatto, M. C. (2006b). The Khartoum Variant pottery in context: Rethinking the Early and Middle Holocene Nubian sequence. Archéologie du Nil Moyen, 10, 57-72.

Gifford, J. C. (1960). The type-variety method of ceramic classification as an indicator of cultural phenomena. American Antiquity, 25(3), 341-347.

Gosselain, O. P. (1998). Social and technical identity in a clay crystal ball. In M. Stark (Ed.), The archaeology of social boundaries (pp. 78-106). Washington, D.C.: Smithsonian Institution Press.

Gosselain, O. P. (2000). Materializing identities: An African perspective. Journal of Archaeological Method and Theory, 7(3), 187-217.

Gosselain, O. P. (2008). Mother Bella was not a Bella. Inherited and transformed traditions in southwestern Niger. In M. Stark, B. Bower, and L. Horne (Eds.), Cultural transmission and material culture: Breaking down boundaries (pp. 150177). Tucson: University of Arizona Press.

Gosselain, O. P., and Livingstone Smith, A. (2013). A century of ceramic studies in Africa. In P. Mitchell and P. J. Lane (Eds.), Oxford: The Oxford handbook of African archaeology.

Haaland, R. (1978). Ethnographic observations of pottery-making in Darfur Western Sudan, with some reflections on archaeological interpretation. In K. Kristiansen and C. PoludanMüller (Eds.), New directions in Scandinavian archaeology (pp. 47-61). Copenhagen: The National Museum of Denmark.

Haaland, R. (1987). Socio-economic differentiation in the Neolithic Sudan. Cambridge Monographs in African Archaeology. Oxford: British Archaeological Reports.

Haaland, R. (2007). Porridge and pot, bread and oven: food ways and symbolism in Africa and the Near East from the Neolithic to the present. Cambridge Archaeological Journal, 17, 165-182.

Haaland, R., and Magid, A. A. (1995). Aqualithic sites along the Rivers Nile and Atbara, Sudan. Bergen: Alma Mater Forlag.

Haour, A., Manning, K., Arazi, N., and Gosselain, O. P. (2010). African pottery roulettes past and present: Techniques, identification and distribution. Oxford: Oxbow Books.

Hassan, F. and Van West, C. (1980). A petrographic examination of Neolithic ceramics from the Kadero site, the Sudan (unpublished manuscript).

Hays, T. R. (1971). The Sudanese Neolithic: A critical analysis. $\mathrm{Ph} . \mathrm{D}$. thesis. Southern Methodist University, Dallas.

Hays, T. R., and Hassan, F. A. (1974). Mineralogical analysis of 'Sudanese Neolithic' ceramics. Archaeometry, 16(1), 71-79.

Hildebrand, E. A., Garcea, E. A. A., Florenzano, A., and Mercuri, A. M. (2018). Multiscalar perspectives on Holocene climatic and environmental changes in the Sahara and Nile Corridor, with special consideration of archaeological sites on Sai Island, Sudan. In A. M. Mercuri, C. D'Andrea, R. Fornaciari, and A. Höhn (Eds.), Plants and people in Africa's Past: Progress in African archaeobotany (pp. 215245). New York: Springer.

Hoelzmann, P., Keding, B., Berke, H., Kröpelin, S., and Kruse, H.-J. (2001). Environmental change and archaeology: lake evolution and human occupation in the Eastern Sahara during the Holocene. Palaeogeography, Palaeoclimatology, Palaeoecology, 169, 193-217.
Honegger, M. (2004). Settlements and cemeteries of the Mesolithic and Early Neolithic at el-Barga (Kerma region). Sudan and Nubia, 8, 27-32.

Honegger, M. (2014). Recent advances in our understanding of prehistory in Northern Sudan. In J. R. Anderson and D. A. Welsby (Eds.), The Fourth Cataract and beyond: Proceedings of the 12th International Conference for Nubian Studies (pp. 19-30). London: British Museum Publications on Egypt and Sudan 1.

Honegger, M., and Williams, M. (2015). Human occupations and environmental changes in the Nile valley during the Holocene: the case of Kerma in Upper Nubia (northern Sudan). Quaternary Science Reviews, 130, 141-154.

Hugot, H. J. (1963). Recherches préhistoriques dans l'Ahaggar nord-occidental de 1950 à 1957. Mémoires du Centre de recherches anthropologiques, préhistoriques et ethnographiques I. Arts et métiers graphiques.

Huysecom, E., Rasse, M., Lespez, L., Neumann, K., Fahmy, A., Ballouche, A., Ozainne, S., Maggetti, M., Tribolo, C., and Soriano, S. (2009). The emergence of pottery in Africa during the tenth millennium cal BC: New evidence from Ounjougou (Mali). Antiquity, 83, 905-917.

Iacumin, P., Di Matteo, A., Usai, D., Salvatori, S., and Venturelli, G. (2016). Stable isotope study on ancient populations of central Sudan: Insights on their diet and environment. American Journal of Physical Anthropology, 160, 498-518.

Jakob, B. and Honegger, M. (2017) From the Mesolithic to the beginning of the Neolithic in Upper Nubia: The sequence of Wadi El-Arab (8300-5400 BC cal). In Honegger, M. (Ed.), Archaeological excavations at Kerma (Sudan), 7 (pp. 42 75). Kerma, Documents de la mission archéologique suisse au Soudan, 7, Université de Neuchâtel.

Jesse, F. (1998). Zur wavy line - Keramik in Nordafrika unter besonderer Berücksichtigung des Wadi Howar (Sudan) und dort des Fundplatzes Rahib 80/87. PhD thesis. University of Köln, Köln.

Jesse, F. (2002). Wavy line ceramics: Evidence from Northeastern Africa. In K. Nelson and Associates (Eds.), Holocene settlements of the Egyptian Sahara. Vol. 2: The pottery of Nabta Playa (pp. 79-96). New York: Kluwer Academic/Plenum.

Jesse, F. (2003a). Rahib 80/87: Ein wavy-line-Fundplatz im Wadi Howar und die früheste Keramik in Nordafrika. Köln: Heinrich-Barth-Institut.

Jesse, F. (2003b). Early ceramics in the Sahara and the Nile Valley. In L. Krzyzaniak, K. Kroeper, and M. Kobusiewicz (Eds.), Cultural markers in the later prehistory of Northeastern Africa and recent research (pp. 35-50). Poznań: Poznań Archaeological Museum.

Jesse, F. (2004). No link between the central Sahara and the Nile Valley? (Dotted) Wavy Line ceramics in the Wadi Howar, Sudan. In T. Kendall (Ed.), Nubian Studies: Proceedings of the Ninth Conference of the International Society for Nubian Studies, Boston 21-26 August 1998 (pp. 296-308). Boston: Museum of Fine Arts and Northeastern University.

Jesse, F. (2006a). Dune habitats in the Wadi Howar, northwest Sudan. In Le Secrétariat du Congrès (Ed.), Actes du XIVème Congrès UISPP, Université de Liège, Section 15: Préhistoire en Afrique (pp. 101-107). Oxford: BAR International Series, 1522.

Jesse, F. (2006b). Time of experimentation? The $4^{\text {th }}$ and $3^{\text {rd }}$ millennia BC in Lower Wadi Howar, Northwestern Sudan. 
In W. Godlewski and A. Lajtar (Eds.), Between the Cataracts 1: Proceedings of the 11th International Conference for Nubian Studies, Warsaw University 27 August - 2 September 2006 (pp. 49-74). Polish Archaeology in the Mediterranean. Supplement Series volume 2, part 1.

Jesse, F., and Keding, B. (2007). Holocene settlement dynamics in the Wadi Howar region (Northern Sudan) and the Ennedi mountains (Chad). In O. Bubenzer, A. Bolten, and F. Darius (Eds.), Atlas of cultural and environmental change in Arid Africa (pp. 42-43). Köln: Heinrich-Barth- Institut.

Jesse, F., Keding, B., Lenssen-Erz, T., and Pöllath, N. (2013). 'I hope your cattle are well': Archaeological evidence for early cattle-centred behaviour in the Eastern Sahara of Sudan and Chad. In M. Bollig, M. Schnegg, and H.-P. Wotzka (Eds.), Pastoralism in Africa: Past, present and future (pp. 66-103). New York: Berghahn.

Keding, B. (1998). The Yellow Nile: new data on settlement and the environment in the Sudanese Eastern Sahara. Sudan and Nubia, 2, 2-12.

Keding, B. (2000). New data on the Holocene occupation of the Wadi Howar region (Eastern Sahara/Sudan). In L. Krzyzaniak, K. Kroeper, and M. Kobusiewicz (Eds.), Recent research into the Stone Age of Northeastern Africa (pp. 99-104). Poznań: Poznań Archaeological Museum.

Keding, B. (2006). Pottery of the Wadi Howar: Traditions, transformations and their implications. In K. Kroeper, M. Chlodnicki, and M. Kobusiewicz (Eds.), Archaeology of Early Northeastern Africa: In memory of Lech Krzyzaniak (pp. 235-259). Poznań: Poznan Archaeological Museum.

Khabir, A. M. (1987a). New radiocarbon dates for Sarurab 2 and the age of the Early Khartoum tradition. Current Anthropology, 28, 377-380.

Khabir, A. M. (1987b). Petrographic and X-ray analyses of Neolithic pottery from Sarurab. Nyame Akuma, 28, 45-46.

Khabir, A. M. (1991a). The firing index of Neolithic pottery from Central Nile. Nyame Akuma, 35, 33-35.

Khabir, A. M. (1991b). A qualitative change in the texture of temper of Neolithic ceramics from the Central Nile Valley. Sahara, 4, 145-147.

Khabir, A. M. (2014). Typological and technological examinations of Neolithic pottery from Khartoum Province, Sudan. In J. R. Anderson and D. A. Welsby (Eds.), The fourth cataract and beyond. Proceedings of the 12th International conference for Nubian Studies (pp. 279-284). London: British Museum Publications on Egypt and Sudan 1.

Kinahan, J. (2013). The acquisition of ceramics by huntergatherers on the Middle Zambezi in the first and second millennium AD. Journal of African Archaeology, 11(2), 197-209.

Klein, M., Jesse, F., Kasper, H. U., and Gölden, A. (2004). Chemical characterization of ancient pottery from Sudan by X-Ray Fluorescence Spectrometry (XRF), Electron Microprobe Analyses (EMPA) and Inductively Coupled Plasma Mass Spectrometry (ICP-MS). Archaeometry, 46(3), 339-356.

Klichowska, M. (1978). Preliminary results of palaeoethnobotanical studies on plant impressions on potsherds from the Neolithic settlement at Kadero. Nyame Akuma, 12, 42-43.

Kröpelin, S. (2007). The Wadi Howar. In O. Bubenzer, A. Bolten, and F. Darius (Eds.), Atlas of cultural and environmental change in arid Africa, Africa Praehistorica, 21 (pp. 38-39). Köln: Heinrich-Barth-Institut.

Krzyzaniak, L. (1991). Early farming in the Middle Nile Basin: recent discoveries at Kadero (Central Sudan). Antiquity, 65, $515-532$.

Kuper, R., and Kröpelin, S. (2006). Climate-controlled Holocene occupation in the Sahara: Motor of Africa's evolution. Science, 313, 803-807.

Kuper, R., and Riemer, H. (2013). Herders before pastoralism: Prehistoric prelude in the Eastern Sahara. In M. Bollig, M. Schnegg, and H.-P. Wotzka (Eds.), Pastoralism in Africa: Past, present and future (pp. 31-65). New York: Berghahn.

Lander, F., and Russel, T. (2020). A southern African archaeological database of organic containers and materials, $800 \mathrm{cal} \mathrm{BC}$ to cal AD 1500: Possible implications for the transition from foraging to livestock-keeping. PLoS ONE, 15(7), e0235226. https://doi.org/10.1371/journal.pone.0235226.

Lane, P. J. (2015). Ethnicity, archaeological ceramics, and changing paradigms in East African archaeology. In F. G. Richard and K. C. MacDonald (Eds.), Ethnic Ambiguity and the African Past (pp. 245-271). Walnut Creek, CA: Left Coast Press.

Lange, M. (2006-2007). Development of pottery production in the Laqiya-Region, Eastern Sahara. In B. Gratien (Ed.), Mélanges offerts à Francis Geus (pp. 243-381). Cahiers de Recherches de l'Institut de Papyrologie et d'Egyptologie de Lille, 26.

Lechtman, H. (1977). Style in technology: Some early thoughts. In H. Lechtman and T. S. Merrill (Eds.), Material culture: style, organization, and dynamics of technology (pp. 3-20). Eagan, MN: West Publishing Company.

Lindahl, A., and Pikirayi, I. (2010). Ceramics and change. An overview of pottery production techniques in northern South Africa and eastern Zimbabwe during the first and second millennium AD. Archaeological and Anthropological Sciences, 2(3), 133-149. https://doi.org/10.1007/s12520010-0031-2.

Linseele, V., and Zerboni, A. (2018). Done with fish? A diachronic study of fishing in the Holocene Nile basin of Sudan. Quaternary International, 471(Part A), 229-240.

Livingstone Smith, A. (2000). Processing clay for pottery in Northern Cameroon: Social and technical requirements. Archaeometry, 42(1), 21-42.

Livingstone Smith, A. (2016). Pottery and politics: making sense of pottery traditions in Central Africa. Cambridge Archaeological Journal, 26(3), 471-491. https://doi. org/10.1017/S0959774316000317.

Macklin, M. G., Toonen, W. H. J., Woodward, J. C., Williams, M. A. J., Flaux, C., Marriner, N., Nicoll, K., Verstraeten, G., Spencer, N., and Welsby, D. (2015). A new model of river dynamics, hydroclimatic change and human settlement in the Nile Valley derived from meta-analysis of the Holocene fluvial archive. Quaternary Science Reviews, 130, 109-123.

Magid, A. A. (1991). Macrofossil plant remains from Shaqadud Cave. In A. E. Marks and A. Mohammed-Ali (Eds.), The late prehistory of the Eastern Sahel: The Mesolithic and Neolithic of Shaqadud (pp. 193-196). Dallas: Southern Methodist University Press.

Magid, A. A. (1995). Plant remains from the sites of Aneibis, Abu Darbein and El Damer and their implications. In R. Håland and A. A. Magid (Eds.), Aqualithic Sites along the Rivers 
Nile and Atbara, Sudan (pp. 147-177). Bergen: Alma Mater Forlag.

Magid, A. A. (2003). Exploitation of flood-plants in the Early and Middle Holocene Blue Nile area, Sudan and neighbouring areas. Complutum, 14, 345-372.

Maines, E., Sellier, P., and Langlois, O. (2018). Revisiter un ensemble funéraire du Néolithique soudanais : Le cimetière Kadruka 18 (fouilles J. Reinold). Routes d'Orient, Horssérie, 3, 16-30.

Manzo, A. (2017). Eastern Sudan in its setting: the archaeology of a region far from the Nile Valley. Oxford: Archaeopress.

Manzo, A., Beldados, A., Carannante, A., Usai, D., and Zoppi, V. (2012). Italian Archaeological Expedition to the Sudan of the University of Naples 'L'Orientale'. 2011 Field Season. Il Torcoliere, Università degli Studi di Napoli L'Orientale.

Maritan, L., Iacumin, P., Zerboni, A., Venturelli, G., Dal Sasso, G., Linseele, V., Talamo, S., Salvatori, S., and Usai, D. (2018). Fish and salt: the successful recipe of White Nile Mesolithic hunter-gatherer-fishers. Journal of Archaeological Science, 92, 48-62.

Marks, A. E. (1987). Terminal Pleistocene and Holocene hunters and gatherers in the eastern Sudan. African Archaeological Review, 5, 79-92.

Marks, A. E., and Fattovich, R. (1989). The later prehistory of the Eastern Sudan: a preliminary view. In L. Krzyzaniak and M. Kobusiewicz (Eds.), Late prehistory of the Nile Basin and the Sahara (pp. 451-458). Poznan Archaeological Museum.

Marks, A. E., Shiner, J. L., and Hays, T. R. (1968). Survey and excavations in the Dongola Reach, Sudan. Current Anthropology, 3, 319-323.

Marks, A. E., Mohammed-Ali, A. S., Peters, J., and Robertson, R. (1985). The prehistory of the central Nile Valley as seen from the eastern hinterlands: Excavations at Shaqadud, Sudan. Journal of Field Archaeology, 12, 262-272.

Mayor, A. (2010). Ceramic traditions and ethnicity in the Niger Bend, West Africa. Ethnoarchaeology, 2, 5-48.

Mohammed-Ali, A. S. (1982). The Neolithic Period in the Sudan, c.6000-2500 B.C. Cambridge Monographs in African Archaeology 139. British Archaeological Reports International Series.

Mohammed-Ali, A. S. (1991). The Mesolithic and Neolithic ceramics from Shaqadud Midden. In A. E. Marks and A. S. Mohammed-Ali (Eds.), The late prehistory of the Eastern Sahel (pp. 65-93). Dallas: Southern Methodist University Press.

Mohammed-Ali, A. S., and Jaeger, S. E. (1989). The early ceramics of the Eastern Butana (Sudan). In L. Krzyzaniak and M. Kobusiewicz (Eds.), Late prehistory of the Nile Basin and the Sahara (pp. 473-479). Warsaw: Polish Academy of Sciences.

Mohammed-Ali, A. S., and Khabir, A. R. M. (2003). The wavy line and the dotted wavy line pottery in the prehistory of the Central Nile and the Sahara-Sahel Belt. African Archaeological Review, 20, 25-58.

Müller, N. S., Kilikoglou, V., Day, P. M., and Vekinis, G. (2010). The influence of temper shape on the mechanical properties of archaeological ceramics. Journal of the European Ceramic Society, 30, 2457-2465.

Myers, O. H. (1958). Abka re-excavated. Kush, VI, 131-141.

Myers, O. H. (1960). Abka again. Kush, VIII, 174-181.
Nassr, A. H. (2016). Late prehistoric sites from the Sabaloka province north of Khartoum on the Eastern bank of the Nile, Sudan. Afrique Archéologie and Arts, 12, 21-42.

Nelson, K. (2002). Introduction. In K. Nelson and Associates (Eds.), Holocene settlements of the Egyptian Sahara. Vol. 2: The pottery of Nabta Playa (pp. 1-8). New York: Kluwer Academic/Plenum.

Ness, K. (2015). Classification systems with a plot: Vessel forms and ceramic typologies in the Spanish Atlantic. International Journal of Historical Archaeology, 19(2), 309-333.

Nicoll, K. (2004). Recent environmental change and prehistoric human activity in Egypt and northern Sudan. Quaternary Science Reviews, 23, 561-580.

Nordström, H. - A.. (1972). Neolithic and A-Group sites. Oslo: Scandinavian University Press.

Nordström, H. - Å. (1981). A fabric analysis of sherds from Sudan. In R. Haaland (Ed.), Migratory herdsmen and cultivating women: The structure of Neolithic seasonal adaptation in the Khartoum Nile Environment: 243. Bergen: Universitetet i Bergen.

Peet, T. E. (1933). The classification of Egyptian pottery. Journal of Egyptian Archaeology, 19, 62-64.

Petrie, W. M. F. (1921). Corpus of prehistoric pottery and palettes. London: Bernard Quaritch.

Posnansky, M. (1961). Pottery types from archaeological sites in East Africa. Journal of African History, 2, 177-198.

Reinold, J. (2001). Kadruka and the Neolithic in the northern Dongola Reach. Sudan and Nubia, 5, 2-10.

Reinold, J. (2006). Les cimetières préhistoriques au Soudan coutumes funéraires et systèmes sociaux. In I. Caneva and A. Roccati (Eds.), Acta Nubica: Proceedings of the $X$ International Conference of Nubian Studies (pp. 139-162). Libreria dello Stato.

Rittmann, A., Gottini, V., Hewers, W., Pichler, H., and Stengelin, R. (1973). Stable mineral assemblages of igneous rocks: A method of calculation. New York: Springer-Verlag.

Roset, J.-P. (1996). La ceramique des debuts de l'Holocene au Niger nord-oriental: Nouvelles datations, bilan des recherches. In G. Aumassip, J. D. Clark, and F. Mori (Eds). The prehistory of Africa (pp. 175-182). UISPP 13, section 15. Forli: Abaco.

Roux, V. (2008). Evolutionary trajectories of technological traits and cultural transmission: A qualitative approach to the emergence and disappearance of the ceramic wheelfashioning technique in the southern Levant during the fifth to the third millennia BC. In M. T. Stark, B. Bowser, and L. Horne (Eds.), Cultural transmission and material culture. Breaking down boundaries (pp. 82-104). Tucson: University of Arizona Press.

Roux, V. (2013). Spreading of innovative technical traits and cumulative technical evolution: continuity or discontinuity? Journal of Archaeological Method and Theory, 20(2), 312330 .

Roux, V. (2016). Ceramic manufacture: The chaîne opératoire approach. In A. Hunt (Ed.), The Oxford handbook of archaeological ceramic analysis (pp. 101-113). Oxford: Oxford University Press.

Roux, V., and Courty, M. A. (2013). Introduction to discontinuities and continuities: theories, methods and proxies for an historical and sociological approach to evolution of past 
societies. Journal of Archaeological Method and Theory, 20, 187-193.

Sadr, K. (1991). The development of nomadism in ancient northeast Africa. Philadelphia: University of Pennsylvania Press.

Sadr, K., and Sampson, G. (2006). Through thick and thin: Early pottery in southern Africa. Journal of African Archaeology, $4(2), 235-252$.

Salvatori, S. (2008). Relative and absolute chronology of R12 Cemetery. In S. Salvatori and D. Usai (Eds.), A Neolithic cemetery in the Northern Dongola Reach. Excavations at site R12 (pp. 139-146). Oxford: Archaeopress.

Salvatori, S. (2012). Disclosing archaeological complexity of the Khartoum Mesolithic: New data at the site and regional level. African Archaeological Review, 29, 399-472.

Salvatori, S., and Usai, D. (2019). The Neolithic and 'Pastoralism' along the Nile: A dissenting view. Journal of World Prehistory, 32, 251-285.

Salvatori, S., Usai, D., and Zerboni, A. (2011). Mesolithic site formation and palaeoenvironment along the White Nile (Central Sudan). African Archaeological Review, 28, 177-211.

Salvatori, S., Usai, D., Faroug, M. A., Di Matteo, A., Iacumin, P., Linseele, V., and Khalid Magzoub, M. (2014). Archaeological evidence at Al Khiday: new insight on the prehistory and history of Central Sudan. In J. R. Anderson and D. A. Welsby (Eds.), The Fourth Cataract and beyond. Proceedings of the 12th International Conference of Nubian Studies (pp. 243-257). Leuven: Peeters.

Salvatori, S., Usai, D., and Lecointe, Y. (Eds.). (2016). Ghaba: An early Neolithic cemetery in Central Sudan. Frankfurt am Main: Africa Magna Verlag.

Schiffer, M. B., and Skibo, J. M. (2008). People and things: A behavioral approach to material culture. New York: Springer-Verlag.

Schild, R., and Wendorf, F. (2010). Late Palaeolithic hunter-gatherers in the Nile Valley of Nubia and Upper Egypt. In E. A. A. Garcea (Ed.), South-Eastern Mediterranean Peoples Between 130,000 and 10,000 Years Ago (p. 89125). New York: Oxbow Books.

Schön, W. (1996). Ausgrabungen im Wadi el Akhdar, Gif Kebir (SW-Ägypten). In Africa Praehistorica, 8. Köln: HeinrichBarth-Institut.

Shepard, A. O. (1956). Ceramics for the archaeologist. Washington, D.C.: Carnegie Institution of Washington.

Shiner, J. L. (1968a). The Khartoum Variant industry. In F. Wendorf (Ed.), The prehistory of Nubia (Vol. 2, pp. 768790). Dallas: Fort Burgwin Research Center and Southern Methodist University Press.

Shiner, J. L. (1968b). The Cataract tradition. In F. Wendorf (Ed.), The prehistory of Nubia (Vol. 2, pp. 535-629). Dallas: Fort Burgwin Research Center and Southern Methodist University Press.

Smith, M. E. (1979). A further criticism of the type-variety system: The data can't be used. American Antiquity, 44(4), 822-826.

Smith, N., Karasik, A., Narayanan, T., Olson, E. S., Smilansky, U., and Levy, T. E. (2014). The pottery informatics query database: A new method for mathematic and quantitative analyses of large regional ceramic datasets. Journal of Archaeological Method and Theory, 21(1), 212-250.

Stark, M., Bishop, R. L., and Miska, E. (2000). Ceramic technology and social boundaries: Cultural practices in Kalinga clay selection and use. Journal of Archaeological Method and Theory, 7(4), 295-332.
Stemler, A. B. L. (1990). A scanning electron microscopic analysis of plant impressions in pottery from the sites of Kadero, El Zakiab, Um Direiwa and El Kadada. Archéologie du Nil Moyen, 4, 87-105.

Usai, D. (2016). A picture of prehistoric Sudan: The Mesolithic and Neolithic periods. Oxford Handbooks Online. https://doi. org/10.1093/oxfordhb/9780199935413.013.56.

Usai, D., Maritan, L., Iacumin, P., Zerboni, A., Linseele, V., and Salvatori, S. (2018). Fish and salt: The successful recipe of White Nile Mesolithic hunter-gatherer-fishers. Journal of Archaeological Science, 92, 48-62.

Varadzinová, L., and Varadzin, L. (2017). Sabaloka (West Bank) Research project exploration of the site of Sphinx (SBK.W60): Findings of the 2014 and 2015 field seasons. Sudan and Nubia, 21, 23-33.

Vogelsang, R., and Keding, B. (2013). Climate, culture, and change: from hunters to herders in Northeastern and Southwestern Africa. In M. O. Baldia, T. K. Perttula, and D. S. Frink (Eds.), Comparative archaeology and paleoclimatology. Socio-cultural responses to a changing world (pp. 43-62). BAR International Series 2456. Oxford: British Archaeological Reports.

Wengrow, D., Dee, M., Foster, S., Stevenson, A., and BronkRamsey, C. (2014). Cultural convergence in the Neolithic of the Nile Valley: A prehistoric perspective on Egypt's place in Africa. Antiquity, 88, 95-111.

Willey, G. R. (1945). Horizon style and pottery traditions in Peruvian archaeology. American Antiquity, 2(I), 49-56.

Williams, M. (2019). The Nile Basin: Quaternary geology, geomorphology and prehistoric environments. Cambridge: Cambridge University Press.

Winchell, F. (2013). The Butana Group ceramics and their place in the Neolithic and Post- Neolithic of Northeast Africa. In Cambridge Monographs in African Archaeology 83. British Archaeological Reports International Series. Oxford: British Archaeological Reports.

Winchell, F., Stevens, C. J., Murphy, C., Champion, L., and Fuller, D. (2017). Evidence for sorghum domestication in fourth millennium BC Eastern Sudan. Current Anthropology, 58(5), 673-683.

Woodward, J. C., Macklin, M. G., and Welsby, D. A. (2001). The Holocene fluvial sedimentary record and alluvial geoarchaeology in the Nile Valley of Northern Sudan. In D. M. Maddy, M. G. Macklin, and J. C. Woodward (Eds.), River basin sediment systems: Archives of environmental change. (pp. 327-356). London: A. A. Balkema.

Wright, J. V. (1968). Type and attribute analysis: Their application to Iroquois culture history. Ontario Archaeology, 11, 65-69.

Zedeno, M. N. (2002). Neolithic ceramic production in the Eastern Sahara of Egypt. In K. Nelson and Associates (Eds.), Holocene settlements of the Egyptian Sahara. Vol. 2: The pottery of Nabta Playa (pp. 51-64). New York: Kluwer Academic/Plenum.

Zerboni, A. (2013). Early Holocene palaeoclimate in North Africa: an overview. In N. Shirai (Ed.), Neolithisation of Northeastern Africa (pp. 65-82). Berlin: Ex Oriente.

Publisher's Note Springer Nature remains neutral with regard to jurisdictional claims in published maps and institutional affiliations. 